\title{
TLR4 Signaling Pathway Modulators as Potential Therapeutics in Inflammation and Sepsis
}

\author{
Nikolay N. Kuzmich ${ }^{1,2, *}$, Konstantin V. Sivak ${ }^{1}$, Vladimir N. Chubarev ${ }^{3}$, Yury B. Porozov ${ }^{2,4}$, \\ Tatiana N. Savateeva-Lyubimova ${ }^{1}$ and Francesco Peri ${ }^{5, *}$ \\ 1 Department of Drug Safety, Research Institute of Influenza, WHO National Influenza Centre of Russia, \\ 15/17 Professor Popov St, Saint-Petersburg 197376, Russia; kvsivak@gmail.com (K.V.S.); \\ drugs_safety@mail.ru (T.N.S.-L.) \\ 2 Laboratory of Bioinformatics, Institute of Pharmacy and Translational medicine, I.M. Sechenov First Moscow \\ State Medical University, 8-2 Trubetskaya St., Moscow 119991, Russia; yuri.porozov@gmail.com \\ 3 Department of Pharmacology, Institute of Pharmacy and Translational medicine, I.M. Sechenov First \\ Moscow State Medical University, 8-2 Trubetskaya St., Moscow 119991, Russia; tchoubarov@mail.ru \\ 4 Laboratory of Bioinformatics, ITMO University, 49 Kronverkskiy Pr., Saint Petersburg 197101, Russia \\ 5 Department of Biotechnology and Biosciences, University of Milano-Bicocca, Piazza della Scienza 2, \\ Milano 20126, Italy \\ * Correspondence: nnkuzmich@gmail.com (N.N.K.); Tel.: +7-921-3491-750 (N.N.K.); \\ francesco.peri@unimib.it (F.P.); Tel.: +39-026-448-3453 (F.P.); Fax: +7-812-499-15-15 (N.N.K.)
}

Academic Editor: Paola Massari

Received: 5 September 2017; Accepted: 1 October 2017; Published: 4 October 2017

\begin{abstract}
Toll-Like Receptor 4 (TLR4) signal pathway plays an important role in initiating the innate immune response and its activation by bacterial endotoxin is responsible for chronic and acute inflammatory disorders that are becoming more and more frequent in developed countries. Modulation of the TLR4 pathway is a potential strategy to specifically target these pathologies. Among the diseases caused by TLR4 abnormal activation by bacterial endotoxin, sepsis is the most dangerous one because it is a life-threatening acute system inflammatory condition that still lacks specific pharmacological treatment. Here, we review molecules at a preclinical or clinical phase of development, that are active in inhibiting the TLR4-MyD88 and TLR4-TRIF pathways in animal models. These are low-molecular weight compounds of natural and synthetic origin that can be considered leads for drug development. The results of in vivo studies in the sepsis model and the mechanisms of action of drug leads are presented and critically discussed, evidencing the differences in treatment results from rodents to humans.
\end{abstract}

Keywords: TLR4; sepsis; LPS; CD14; MD-2; in vivo studies; PAMP; DAMP

\section{Introduction}

Toll-like Receptors (TLRs) are type I transmembrane proteins and are a panel of conserved pattern-recognition receptors (PRR) that are activated by a variety of pathogen-associated molecular patterns (PAMPs), thus initiating an innate immune response and inflammation in higher animals [1,2]. Toll-Like Receptor 4 (TLR4) is the member of TLR family that recognizes and is activated by bacterial lipopolysaccharide (LPS), which is the main molecular component of the cell wall of Gram-negative bacteria [3-5]. As other TLRs, TLR4 has a modular structure composed by a domain constituted by leucine-rich repeats (LRR) [6] in the extracellular part, connected to an intracellular TIR domain responsible for the signal transmission. Molecular recognition of minute amounts of circulating LPS (endotoxin) by the TLR4 receptor system, followed by receptor dimerization on the cell membrane, starts the cascade of protein-protein interactions leading to the production of pro-inflammatory cytokines and interferons, thus launching the inflammatory and immune responses. 


\subsection{The Extracellular TLR4 Receptor System}

TLR4 does not bind LPS directly, and the adaptor protein MD-2 (also known as lymphocyte antigen 96 [7] is required, that directly binds and recognizes the lipophilic part of LPS (lipid A) forming a discrete complex [8,9]. It associates non-covalently to TLR4 to form the final activated heterodimer (LPS/MD-2/TLR4) 2 [10] that in its turn starts the intracellular signal (Figure 1).

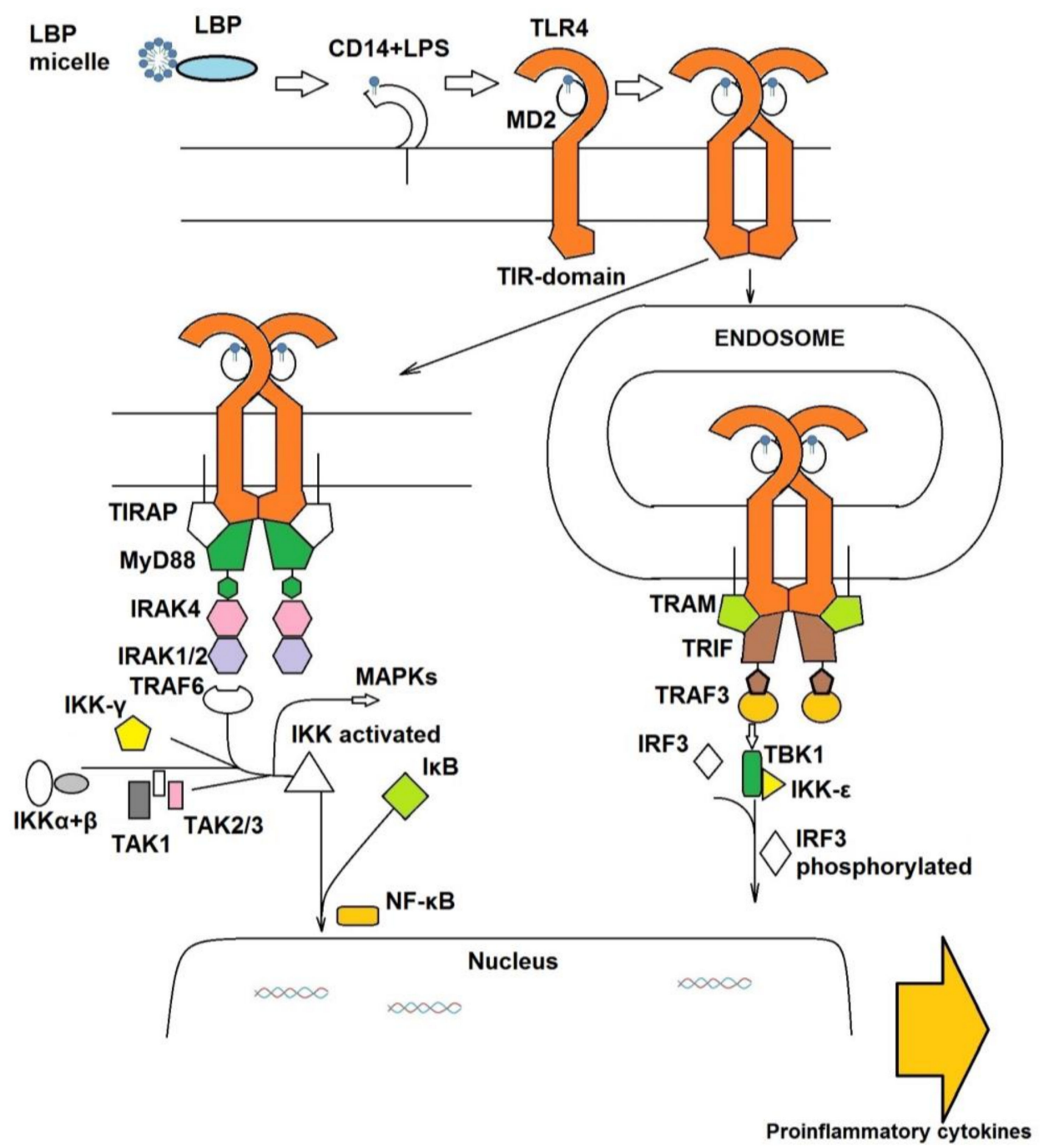

Figure 1. The lipopolysaccharide (LPS)/toll-Like Receptor 4 (TLR4) signaling pathway: the extracellular part (mediated by LPS-binding protein (LBP), cluster of differentiation 14 (CD14) and MD-2) and the intracellular part (myeloid differentiation primary response gene (MyD88) and TIR-domain-containing adapter-inducing interferon- $\beta$ (TRIF) branches).

The dimerization of TLR4 is promoted by key interactions between MD-2, endotoxin's lipid A sugars and fatty acid chains, and the two TLR4 (named TLR4 and TLR4') on the extracellular side and by interactions of TIR domains (mainly TIR/TIR surfaces interactions) of the two TLR4 on the inner side [10]. TLR4 activation by LPS is accomplished through a series of sequential steps in which LPS is bound by different LPS-binding proteins and transferred to MD-2/TLR4 [11]. The LPS-binding protein (LBP) binds a LPS monomer from LPS aggregates in solution, transfers this molecule to cluster of differentiation 14 (CD14) protein, that finally chaperones the formation of the complex of LPS with MD-2/TLR4 [12]. CD14 is expressed mainly in macrophages and monocytes, as TLR4 it has leucine-rich 
repeats (LRR) and occurs in both soluble and membrane-bound (through a glycophosphatidylinositol (GPI) anchor) forms [13].

\subsection{The Intracellular Signal Cascade}

Once the sequential action of LBP and CD14 has promoted the formation of the activated TLR4/MD-2 heterodimer on the cell surface, the intracellular signal can follow one of two distinct directions, the TLR4/MyD88/NF-kB and TLR4/TRIF/IRF3 pathways (Figure 1). For further downstream signaling, the adaptor proteins MyD88 (myeloid differentiation primary response gene 88), TIRAP (TIR domain-containing adaptor protein), TRAM (TRIF-related adaptor molecule), and TRIF (TIR-domain-containing adapter-inducing interferon- $\beta$ ) are necessary [14]. The intracellular part of TLR4 and all of the TLR4 adaptor proteins possess Toll/interleukin-1 receptor (TIR) domains that are responsible of mutual interactions [14]. MyD88-dependent and TRIF-dependent pathways are competitive and mutually exclusive [15]. TLR4/MyD88 pathway starts from the (LPS/MD-2/TLR4) 2 complex located on plasma membrane, whilst TLR4/TRIF transduction begins after complex internalization into endosomes. It is possible to dissect the two pathways by using molecules that selectively act on endocytosis. Shim et al. discovered that the anti-inflammatory action of some antimicrobial peptides is based on the inhibition of TLR4 endocytosis in LPS-stimulated cells that also blocks the TRIF-dependent branch of TLR4 signaling [16]. Interestingly, it has also been observed that CD14 plays a key role in promoting the internalization of TLR4-MD2-LPS complex into endosomes [17].

In the MyD88-dependent pathway, the TIRAP adaptor is recruited to the TIR-TIR dimer of the two TLR4 constituting the activated heterodimer, and the binding occurs via its TIR-domain. TIRAP is an intracellular protein and possesses a phosphatidylinositol 4,5-bisphosphate-binding domain that is necessary for membrane anchoring, and forms a homodimer $[18,19]$. It binds to the TIR-domains of TLR4 and together they form interface for arrival and joining of MyD88.

MyD88 molecules form a complex and bind serine/threonine kinases, Interleukin-1 receptor-associated kinases 2 and 4 (IRAK2 and IRAK4), forming the so-called myddosome. The structure of the complex has been structurally resolved by X-ray crystallography [20]. It has been revealed that the stoichiometric ratio of MyD88-IRAK2-IRAK4 ensemble is 6:4:4. The myddosome formation promotes IRAK4 autophosphorilation [21]. IRAK1 can also bind to the MyD88-IRAK4 complex and be phosphorylated by IRAK4.

Next, TNF receptor associated factor 6 (TRAF6) is recruited, which forms a trimer [15]. It binds to phosphorylated IRAK1 and TRAF6, E3 ubiquitin ligase, promotes poly-ubiquitination of itself at Lys63 site. Polyubiquitin chains of TRAF6 are recognized by TAB2/TAB3 adaptor proteins and IKK $\gamma$ subunit of IKK-complex [21]. It allows for the recruitment and activation of TAK1 and phosphorylation of IKB complex, respectively, promoting its degradation and release of NF- $\mathrm{KB}$ [22]. TAK1 activates various mitogen-activated protein kinases [23], and along with NF- $\mathrm{kB}$ they induce the production and release of proinflammatory cytokines IL-1 $\beta$, TNF- $\alpha$ and IL-6 [24].

Analogously, binding the TRIF-related adaptor molecule (TRAM) to the intracellular TLR4-TIR domains is necessary for adaptor recruitment in the TLR4/IRF3 pathway [25]. Just as TIRAP, TRAM is a membrane-bound bridging adaptor [26] and forms a homo-oligomer [27]. The importance of TRIF for LPS response have been demonstrated in vivo, when TRIF-KO mice were protected from severe sepsis in the cecal ligation and puncture (CLP) model [28]. To activate and to recruit IRF3, phosphorylation of TRIF is required [29]. Phosphorylated IRF-3 then dimerizes and translocates to the nucleus to initiate the transcription of the IFN- $\beta$ gene [30].

\section{Pathologies Related to TLR4 Signaling}

In addition to PAMPs, TLR4 can be also activated by damage-associated molecular patterns (DAMPs) derived from damaged and necrotic tissues (sterile inflammation), such as fibronectins, small fragments of hyaluronan, and even saturated fatty acids in response to cellular damage [31]. Besides the exogenous stimuli, endogenous host molecules, such as the oxydized phospholipids or 
high-mobility group box 1 (HMGB1) have also been shown to activate TLR4 [32,33]. While different LPS shares a conserved lipid A moiety with chemical determinants that ensure the optimal interaction with CD14 and MD-2 (5 or 6 lipophilic fatty acid chains attached to a disaccharide backbone, and one or two phosphate groups) DAMPs are chemically diverse molecules and the molecular mechanism of TLR4 activation including the role of CD14 and MD-2 in the sensing of these molecules are not entirely understood. DAMPs have been implicated in many pathologies caused by TLR4 activation, including atherosclerosis [34], rheumatoid arthritis [35], neuroinflammation [36], and trauma and hemorrhage [37]. Very recently, TLR4 has been suggested as a promising therapeutic target for drug abuse [38] and major depressive disorders [39,40], as well as amyotrophic lateral sclerosis [41]. Possible application of TLR4 antagonists in treatment of peripheral neuropathic pain has also been discussed $[42,43]$.

\subsection{Sepsis and Septic Shock}

Among PAMP/TLR4 diseases, sepsis is the most serious one. It is an excessive and dysregulated response of the host organism to outer pathogens, which leads to acute life-threatening organ dysfunction [44,45]. The global incidence of this syndrome accounts for 437 per 100,000 person-years between the years 1995 and 2015, according to retrospective analysis of an international database [46]. In western countries, mortality in patients with severe sepsis is $20-50 \%$, if there is no organ dysfunction it can be diminished (less than 20\%) [47]. Septic shock with increased lipopolysaccharide (LPS) levels in blood, overexpression of pro-inflammatory cytokines, activation of blood coagulation system, and accumulation of fibrinogen degradation products leads to a violation of local and general hemodynamics and endothelial dysfunction via toll-like receptors signaling pathway [48].

Sepsis is also one of the possible complications of severe influenza. The most typical flora complicating disease is Streptococcus pneumoniae, Pseudomonas aeruginosa, Acinetobacter spp., Staphylococcus aureus, as well as Enterobacteriaceae spp. [49], Aspergillus spp. [50] and other.

Moreover, it has been recently discovered that the lethality of some influenza virus strains (human pandemic H1N1 or PR8) is due to abnormal TLR4 activation by endogenous factors (DAMPs), such as oxidized phospholipids, generated as a consequence of the acute lung injury (ALI) caused by the viral infection [51,52].

Because of TLR4 signaling cascade's huge role, its extracellular and intracellular components are very attractive therapeutic targets for the treatment of both acute (e. g., sepsis) and chronic disorders, associated with excessive cytokine production (also called, in the case of sepsis, cytokine storm) [53-58].

\subsection{Animal Models of Sepsis}

Rodents have been widely used as animals for studying sepsis. Several models have been developed so far-LPS treatment, administration of viable pathogens, and caecal ligation and puncture model (CLP) [59-62]. In the latter case the endogenous protective barrier is damaged and pathogen efflux follows.

LPS injection model is easy to perform and the induced inflammatory response has a good reproducibility. High levels of pro-inflammatory cytokines are released soon and systemic inflammatory response syndrome (SIRS) develops rapidly followed by dose-dependent mortality. The disadvantage of this method is that pathophysiological aspects of human sepsis are not fully reproduced [60]. Bacterial injection model (also known as peritoneal contamination and infection model, PCI) is better since it mimics microbial sepsis and especially the polymicrobial one, which cannot be induced by endotoxin administration although extensive bacteremia is rarely observed by sepsis patients [63].

CLP model is the most widely used one and is considered to describe best the human sepsis. The bacterial endotoxin release into the bloodstream is relatively slow and can be adjusted by the number and size of punctures $[64,65]$. With respect to the IL-6 and TNF- $\alpha$, hemodynamic, and biochemical responses CLP model is the most comparable to human sepsis $[66,67]$. 
Various compounds have been tested on animal models for their capacity to block TLR4-mediated cytokine production, and several have reached the clinical trials. The known TLR4 antagonists belong to various classes of chemical compounds-mainly glycolipids that mimic the natural TLR4 ligand, lipid A, but also heterocycles, peptides, opioids, taxanes, steroids, etc, and have natural and synthetic origin.

\section{TLR4 Antagonists from Natural Sources}

Plant secondary metabolism provides a vast source of chemically diverse bioactive and pharmacologically active compounds. Traditional Chinese and Indian medicine use a variety of herbs that are rich in molecules that very likely act as TLR4 modulators. TLR4 activation or inhibition mediated by herbal extracts promoted a vast area of research that focuses on the molecular mechanism of action of these TLR4 modulators.

Berberine (Figure 2), an isoquinoline alkaloid mainly extracted from Rhizoma Coptidis, significantly postponed the death after intraperitoneal LPS (from Salmonella thyphimurium LT2) injection in mice, decreased the body temperature on LPS-generated fever in rabbits, and inhibited the increasing of nuclear factor kappa-light-chain-enhancer of activated B cells (NF-kB), interleukin-6 (IL-6), tumor necrosis factor alpha (TNF- $\alpha$ ), and interferon-beta (IFN- $\beta$ ) expressions (real-time PCR analysis of mRNA expression) [68]. Docking studies were done by using Autodock 4.2 software [69,70]. AutoDock 4 is based on free energy force field parameterized using a large number of protein inhibitor complexes. For both inhibition constants $(\mathrm{Ki})$ and structures are known. Docking analysis suggested that berberine can bind to MD-2 and that the MD-2 hydrophobic binding pocket is able to accommodate up to three berberine molecules [68]. Besides binding to MD-2, berberine also blocks TLR4/NF- $\mathrm{B}$ transduction at a later stage directly binding the cysteine 179 residue of I $\kappa B$ kinase (IKK), and thus suppressing NF- $\kappa B$ activation through the inhibition of phosphorylation and degradation of $\mathrm{I} \kappa \mathrm{B} \alpha$ [71]. Because its dual targeting (MD-2, extracellular and IKK, intracellular), berberine can be considered a promising hit to develop drugs that efficiently block the LPS/TLR4 signaling at different points.

Parthenolide (Figure 2) is a known inhibitor of the TLR4/NF-kB pathway [72]. It has been observed in human leukemia monocytic THP-1 cells that the LPS-stimulated production of TNF- $\alpha$, as well as the production of various interleukins (IL-6, IL-1 $\beta$, IL-8, IL-12p40, IL-18), were reduced more than $50 \%$ by the administrating parthenolide. Moreover, parthenolide was active in reducing levels of TLR4 expression after LPS activation. Similar results were obtained on human keratinocytes [73]. Biochemical studies suggest that this sesquiterpene lactone blocks both the MyD88- and TRIF branches of TLR4 signal pathway [74,75]. However, in vivo studies performed on different murine strains led to ambiguous results. In the LPS-induced septic shock model on Swiss albino rats, the administration of parthenolide improved survival [76]. On the contrary, parthenolide failed to improve and even deteriorated survival on C57BL/6J mice [77] on the same model of LPS-induced septic shock. The mechanism of action of parthenolide has been investigated by means of computational studies (AutoDock4) and it has been proposed that the TLR4 antagonism is due to parthenolide binding to TNF receptor associated factor 6 (TRAF6) [78]. 


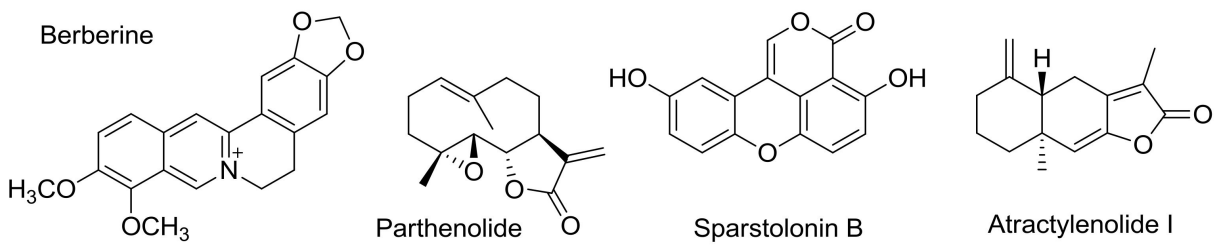

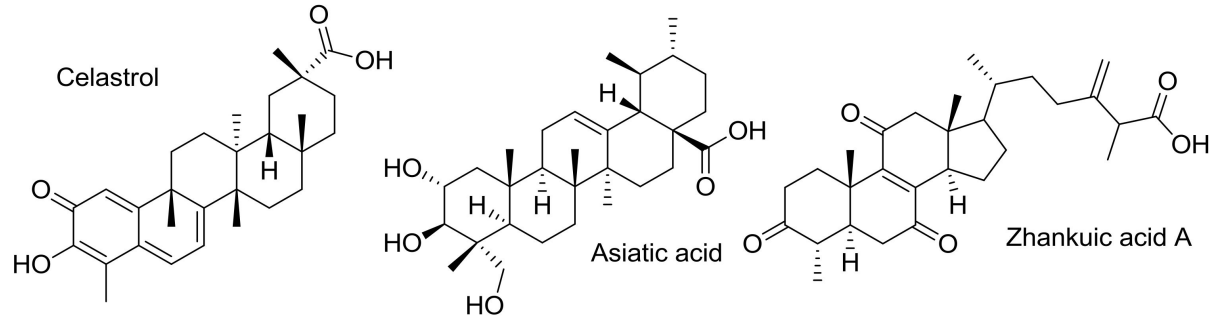<smiles>COC(=O)C1=COC(O)[C@H]2C(CO)=CC[C@H]12</smiles>

Genipin<smiles>CS[C@]1(C)NC(=O)[C@@](CO)(SC)NC1=O</smiles>

Chlorogenic acid<smiles>CC1=CC(=O)C(C(C)C)=CC1=O</smiles>

Thymoquinone

Figure 2. Natural compounds with TLR4-antagonistic properties, tested in vivo on animal models of sepsis.

Sparstolonin B (SsnB) isolated from a Chinese herb (Sparganium stoloniferum) (Figure 2), was found to significantly inhibit the expression of the cytokines TNF- $\alpha$, IL- 6 , and IL- $1 \beta$ induced by LPS (mRNA concentrations of cytokines were measured by quantitative real-time PCR).

Treatment of macrophages with SsnB and LPS also caused several-fold decrease in TNF $\alpha$ and IL-6 levels, if compared with group treated by LPS only [79]. In this case, cytokine concentrations were measured by ELISA. In addition, SsnB attenuates TLR4-mediated NF- $\kappa$ B activation in a dose-depending manner and inhibits myeloid differentiation primary response gene 88 (MyD88) recruitment to TLR4 and suppresses LPS-provoked inflammation in mice (decrease in TNF- $\alpha$ and interleukin 1 beta (IL-1 $\beta$ ) expression was statistically significant) [80]. Another study has demonstrated that SsnB increased the survival rate (4-fold) after intraperitoneal LPS administration both treating with SsnB before and after LPS administration. Additionally, pretreatment with SsnB significantly alleviated the lung pathology caused by LPS-injection. The latter two experiments were performed on mice [80]. Inhibition of LPS-induced inflammation in 3T3-L1 adipocytes [81] and human umbilical vein endothelial cells was also observed [82].

Atractylenolide I (Figure 2), a bioactive component of Rhizoma Atractylodis macrocephalae, significantly decreased LPS-induced TNF- $\alpha$, IL-6, nuclear NF-kB p65 factor, extracellular signal-regulated kinases (ERK) 1 and 2, and p38 production by murine macrophage-like RAW264.7 cells [83]. Expression levels of MD-2, CD14, complement receptor 3 (CR3), SR-A, TLR4, and MyD88 were also significantly attenuated, as shown by Western blot analysis. This sesquiterpenoid has also proven to be effective in vivo. It protects mice from acute lung injury (ALI) induced by LPS [84] and significantly increased the survival rate on sepsis induced by CLP [85]. In this context, one can speculate that atractylenolide is active in antagonizing DAMP/TLR4 signaling. The normalization of liver and kidney functions as well as a significant decrease in serum cytokine levels was also observed. According to the docking studies, the possible mechanism of action for artactylenolide I involves binding to MD2 protein and preventing its interaction with LPS or DAMPs [86].

Zhankuic acid A (ZAA, Figure 2), isolated from the mushroom Taiwanofungus camphoratus, which is highly valued in Chinese traditional medicine, is a triterpenoid with a steroid structure. ZAA 
significantly blocks LPS-induced phosphorylation of ERK, c-Jun N-terminal kinase (JNK), p38, AKT, as well as NF- $\mathrm{kBp} 65$ phosphorylation, thus blocking NF-kB, mitogen-activated protein kinase (MAPK), and AKT signaling pathways. LPS- and Salmonella choleraesuis - induced TNF- $\alpha$ and IL-6 in vivo and in vitro production in RAW264.7 cells were both attenuated [87]. At a dose of $10 \mathrm{mg} / \mathrm{kg}$ (C3H mice, i.p.), ZAA was active in prolonging survival after LPS administration at the LD50 concentration $(100 \%$ increase, $p<0.001$ ). In the same conditions, $2 \mathrm{mg} / \mathrm{kg}$ of ZAA provided a $30 \%$ increase in survival as compared to control mice treated with LPS only. However, this variation is not statistically significant.

Docking studies (Dock 5.1 software [88]) proposed that ZAA can interact with the hydrophobic binding pocket of MD-2, that accommodates the lipophilic chains of lipid A, the natural MD-2 ligand. Dock 5.1 employs incremental construction for ligand sampling, merged target structure ensemble for receptor sampling, force-field based scoring function and distance dependent dielectric, generalized Born, and linearized Poisson-Boltzmann models. Consensus scoring analysis performed using the XScore scoring function [89] after generating binding pose predicted $\mathrm{pK}_{\mathrm{d}}$ value of ZAA as high as 7.83, being two orders of magnitude higher than the reference substance LPS itself $\left(\mathrm{pK}_{d}=5.83\right)$. However, no experimental data supporting direct binding of ZAA to MD-2 have been reported so far.

The triterpenoids celastrol and asiatic acid (Figure 2) are also active in disrupting TLR4 signaling. Experimental binding studies showed that celastrol binds non-covalently to MD-2 and then the interaction evolves in a covalent binding through Michael addition of celastrol to a thiol group of an MD-2 cysteine [90]. Both in vitro and in silico studies showed that celastrol compete with LPS for MD-2 binding [91]. Asiatic acid significantly diminished LPS-induced lung injury by male BALB/c mice in a dose-dependent manner [92]. Several other triterpenoids also exhibited IKK $\beta$ mediated activation [93].

Inhibition of both MyD88- and TRIF-dependent branches of TLR4-signaling was also observed by genipin, an aglycon of geniposide [94] and bis-N-norgliovictin, isolated from a marine fungus [95] (Figure 2). Genipin improved the survival of male ICR mice in both endotoxemia and CLP sepsis. The study of Kim and coworkers showed that attenuation of apoptotic depletion of T lymphocytes also contributes to the better survival in sepsis [96]. Bis-N-norgliovictin also improved survival after LPS administration, decreased serum cytokine levels and reduced lungs, and liver damage.

Chlorogenic acid (CGA) (Figure 2) is a major component of lonicerae flos extract. Intravenous administration of CGA protected C57BL/6 mice from septic shock after intraperitoneal LPS challenge [97]. At the dosage $3 \mathrm{mg} / \mathrm{kg}$ (CGA), the survival rate was increased up to $70 \%$. In addition, the cytokine levels in blood of treated animals were decreased, too. In vitro, kinase assays demonstrated that MAPK activation was blocked by CGA, as well as auto-phosphorylation of IRAK4. Protein or mRNA levels of TNF- $\alpha$, IL- $1 \alpha$, and HMGB-1 (high-mobility group box-1) in the peritoneal macrophages, induced by LPS, were also attenuated by CGA treatment.

Lonicerae flos extract (HS-23) itself has demonstrated similar results [98]. Apart from CGA, the extract also contains its isomers, cryptochlorogenic, and neochlorogenic acids, and also glycosides loganin and vogeloside. Loganin was found to inhibit NF- $\mathrm{kB}$ activation [99]. Moreover, HS-23 recently underwent stages I and II of clinical trials [98].

Thymoquinone (Figure 2) was proven to inhibit another interleukin-1 receptor-associated kinase, namely IRAK1 [100]. Preventive administration of thymoquinone significantly improved survival of albino mice after both E.coli and E.coli-derived LPS challenge $(p<0.01$, log-rank test) [101]. Later, this group showed that organ dysfuction accompanying sepsis was diminished after treatment by this quinone [102]. The therapeutic potential of IRAK4 blocking has been outlined by Li [103]. Several reviews focused on IRAK4-inhibitors and their possible applications of inflammation and oncology disorders have been published recently [104-108].

Artesunate (AS) (Figure 3), a hemisuccinate derivative of dihydroartemisinin soluble in water, promoted to the decrease of TNF- $\alpha$ and IL6 levels in mouse peritoneal macrophages induced LPS, or heat-killed E. coli [109]. Pretreatment of Kunming mice with AS significantly decreased mortality and delayed the time of death. Endotoxin and TNF- $\alpha$ levels were also decreased dose-dependently. 
The suppression of TLR4/MyD88/NF-KB signaling pathway by AS was also observed in murine BV2 microglial cells [110]. The natural compound artemisinin (Figure 3), a precursor of AS, have also demonstrated a similar activity in vivo [111].
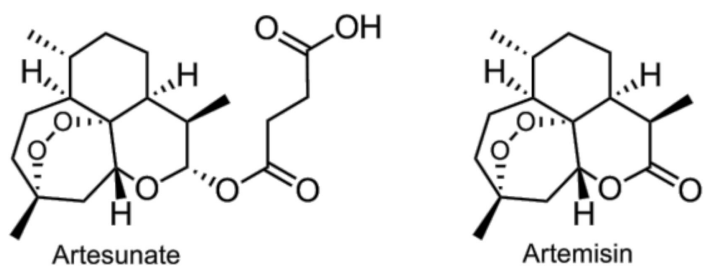

Figure 3. Artesunate and artemisinin.

Recently, it has been discovered by Li et al. [112] that corilagin (Figure 4), which belongs to the group of hydrolysable tannins, also attenuates system inflammation in vivo after LPS injection. When administrated at a dose of $40 \mathrm{mg} / \mathrm{kg}$, corilagin significantly decreased LPS-iduced lethality of Balb/c mice. In liver tissue the expression of TLR4, MyD88, TRIF, and TRAF6 proteins was increased after LPS injection also in animals treated with corilagin, but to a lower extent than in control animals treated with only LPS. In mouse serum, the same pattern of changes for IL-6, IL-1 $\beta$ levels was also observed. Epigallocatechin-3-gallate (EGCG) (Figure 4) is the most abundant polyphenolic flavonoid contained in green tea. Singh and co-workers [113] discovered that EGCG blocked TLR4/NF-kB pathway and selectively inhibited phosphorylation of TAK1 at the Thr184/187 site leading to a loss of its kinase activity. Inhibiting K63 auto-ubiquitination of TRAF6 was also observed. In experimental sepsis EGCG e treatment significantly improved both the hypotension in Sprague-Dawley rat and the survival of C57BL6 mice [114].<smiles>O=C(OC[C@H]1O[C@H](OC(=O)c2cc(O)c(O)c(O)c2)[C@H](O)[C@H](OC(=O)c2cc(O)c(O)c(O)c2-c2c(O)c(O)c(O)c(O)c2O)[C@@H]1O)c1ccccc1</smiles><smiles>O=C(O[C@H]1Cc2c(O)cc(O)cc2O[C@@H]1c1cc(O)c(O)c(O)c1)c1cc(O)c(O)c(O)c1</smiles>

Figure 4. The polyphenols corilagin (left) and epigallocatechin gallate (right).

\section{Synthetic TLR4 Antagonists}

\subsection{TAK-242 and Eritoran: Clinical Trials}

Several TLR4 antagonists were synthesized, the majority of them being mimetics of lipid A, the natural MD-2 ligand [115]. Lipid A is a glucosamine disaccharide with two phosphate groups in C1 and C4' positions and six fatty acid chains. The binding of lipid A to MD-2/TLR4 is driven by the hydrophobic interaction of the fatty acid chains of lipid A with the MD-2 hydrophobic binding cavity, as well as polar interactions of the disaccharide backbone and phosphates with MD-2 residues at the rim of the cavity [10]. The most famous lipid A mimetic is Eisai's Eritoran (Figure 5) that entered clinical phase. Other TLR4 antagonists with a chemical structure unrelated to lipid A have been recently developed. However, only TAK-242 (resatorvid, Figure 5) entered clinical trials. 


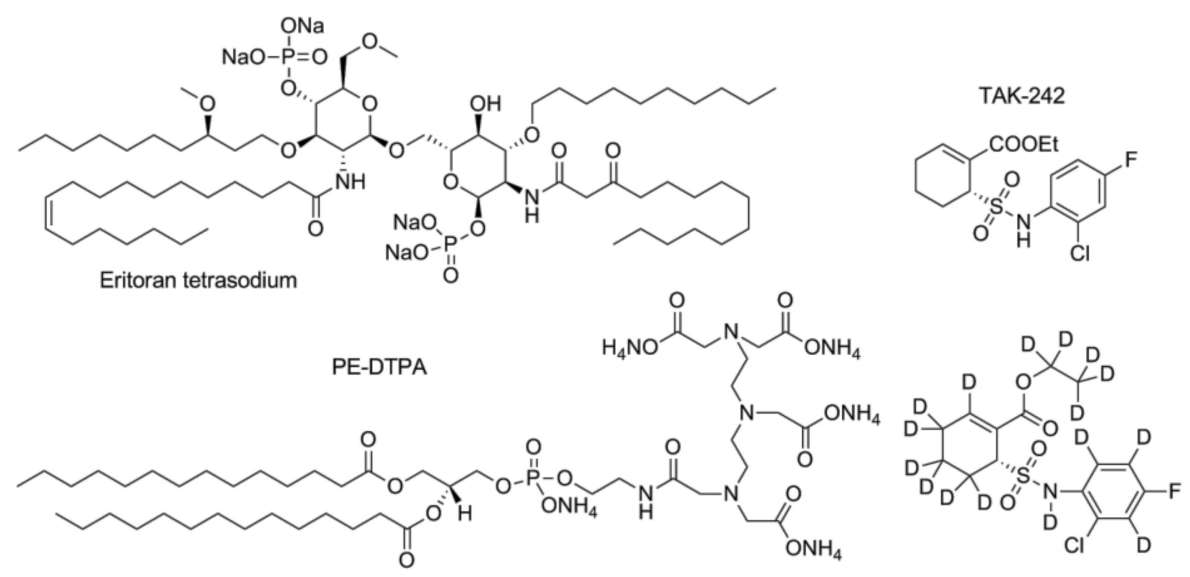

Figure 5. Eritoran tetrasodium, PE-DTPA, TAK-242 (resatorvid) and its deuterated analogue.

TAK-242 (resatorvid) (Figure 5) is a small-molecule compound that selectively inhibits TLR4 signaling. TAK-242 inhibits the TLR4 pathway by binding directly to a Cys747 in the intracellular TLR4 domain [116] . It has been observed that TAK-242 disrupts the interactions of TLR4 with its adaptor molecules, TIRAP (toll-interleukin 1 receptor (TIR) domain containing adaptor protein), and TRAM (TIR domain-containing adapter inducing IFN- $\beta$-related adapter molecule). Treatment of the HEK293 cells transfected with plasmids encoding FLAG-TLR4, MD-2, and FLAG-TIRAP/FLAG-TRAM proteins with TAK-242 inhibited the co-precipitation of TIRAP with TLR4 in a concentration-dependent manner. TAK-242 inhibited the association of TRAM with TLR4 at concentrations similar to those at which it inhibited the association of TIRAP with TLR4. Another study also confirmed this mechanism of action [117].

Several other studies demonstrated the efficiency of TAK-242 on the murine sepsis model at both single and combined therapies [118,119]. Apart from the above, TAK-242 also protects against acute cerebral ischemia/reperfusion injury in mice by dose of $3 \mathrm{mg} / \mathrm{kg}$ [120]. On the acute kidney injury model (sheep, i.v.) there was a protective effect observed. The pathologic condition was induced by E. coli-derived LPS [121]. Several studies demonstrated TAK-242 anti-inflammation activity in other rodent species than mice $[122,123]$. Eventually, TAK-242 was admitted to the clinical trials. In a randomized, double-blind, placebo-controlled trial, embracing 274 patients with severe sepsis and shock or respiratory failure, there were two dose groups receiving TAK-242 1.2 and $2.4 \mathrm{mg} / \mathrm{kg} /$ day, respectively, and one group receiving the placebo. TAK-242 failed to suppress the interleukin-6 level even at a high dose group $(p=0.15)$. Organ-dysfunction assessments did not reveal any differences between placebo and treated groups. Finally, 28-day survival did not differ significantly between the treatment groups ( $p=0.46$, log-rank test) [124].

Fully deuterated TAK-242 (Figure 5) retains TLR4-antagonistic activity, while having better pharmacokinetic and distribution properties than TAK-242 [125].

Eritoran is probably the most known antagonist of TLR4. It mimics the lipid A, but presents four instead of six fatty acid chains, one of them being unsaturated. The crystallographic analysis of the Eritoran/MD-2 complex revealed that Eritoran binds MD-2 more similarly than lipid A, by accommodating the four fatty acid chains into MD-2 binding pocket [126]. However, when bound to MD-2 cavity, Eritoran is rotated $180^{\circ}$ respect to lipid A [126]. According to this model, Eritoran acts thus as a classic competitive inhibitor of MD-2 competing with LPS for the binding of the MD-2 pocket. After successful results were obtained on animal models, Eritoran was suggested for testing on humans [127-129]. The pharmacodynamics study showed Eritoran to be safe and well-tolerated [130]. Later, at the phase 2 of clinical trials, Eritoran failed to diminish mortality rate even at a high dose $105 \mathrm{mg}$ (compared with placebo group, $p=0.335$ ). The study was performed as prospective, randomized, double-blind, placebo-controlled, multicentre one [131]. Unfortunately, 
another randomized, double-blind, placebo-controlled, multinational phase 3 trial in 197 intensive care units did not show the optimistic results either. The all-cause mortality was not reduced for the primary (28 days) and secondary (1 year) end-points [132].

Results of clinical studies for TLR4-signaling blockers are summarized in Table 1. Phase 1 clinical trials of Eritoran are summarized in the review [128].

Table 1. Results of the phase II and III clinical trials for TLR4-antagonists.

\begin{tabular}{|c|c|c|c|}
\hline $\begin{array}{c}\text { Substance } \\
\text { name }\end{array}$ & Mechanism of action & Clinical trial, design and results & Reference \\
\hline $\begin{array}{c}\text { TAK-242 } \\
\text { (Resatorvid) }\end{array}$ & $\begin{array}{l}\text { Binds covalently to Cys747 of } \\
\text { TLR4-TIR domain and blocks } \\
\text { TLR4/TIRAP and } \\
\text { TLR4/TRAM interactions }\end{array}$ & $\begin{array}{l}\text { Randomized, double-blind, placebo-controlled } \\
\text { phase } 2 \text { trial ( } 274 \text { patients). Failed to suppress } \\
\text { cytokine levels in patients with sepsis and } \\
\text { shock or respiratory failure. }\end{array}$ & [124] \\
\hline $\begin{array}{l}\text { Eritoran } \\
\text { (E5564) }\end{array}$ & Lipid A mimic, binds to MD-2 & $\begin{array}{l}\text { Phase } 2 \text {, double-blind, placebo-controlled, } \\
\text { ascending-dose study (152 patients). Eritoran } \\
\text { was well tolerated but did not attenuated } \\
\text { systemic inflammation significantly. } \\
\text { Randomized, double-blind, placebo-controlled, } \\
\text { multinational phase } 3 \text { trial (1961 patient). } \\
\text { Treatment did not improve 28-day survival. } \\
\text { Prospective, randomized, double-blind, } \\
\text { placebo-controlled, multicenter, } \\
\text { ascending-dose phase II trial (293 patients). } \\
\text { Eritoran was well tolerated but the mortality } \\
\text { was not decreased significantly. }\end{array}$ & [131] \\
\hline
\end{tabular}

\subsection{Synthetic Cationic and Anionic Amphiphiles}

A synthetic phospholipid analogue, the cationic amphiphile 1,2-dimyristoyl-sn-glycero-3phosphoethanolamine-N-diethyle-netriaminepentaacetic acid (also known as PE-DTPA, Figure 5), improved the survival of LPS-treated C57BL/ 6 mice in a dose-dependent manner, as compared with group of animals given LPS alone [133].

Other cationic amphiphiles (IAXO compounds, Figure 6) based on monosaccharide scaffolds efficiently inhibited TLR4 signaling in vitro and in vivo [134].

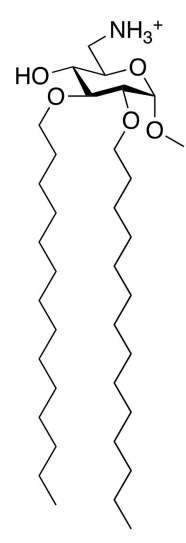

IAX0102

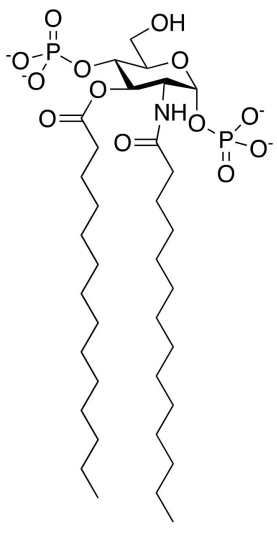

FP7

Figure 6. Positively and negatively charged monosaccharides active as TLR4 antagonists

The mechanism of the antagonist action of this class of compounds was studied in the case of IAXO-102 (Figure 6). A direct interaction of hydrophobic fatty acid chains of this compound and 
MD-2 was found by NMR measurements [135], confirming that very likely these compounds directly compete with LPS for MD-2 binding. Moreover, it has been observed in in vitro binding tests high affinity of IAXO compounds for CD14 [135], so that interaction with CD14 probably reinforces the antagonist effect on the TLR4 signal pathway.

Based on the success of IAXO compounds in inhibiting TLR4 signaling, other cationic amphiphiles were developed as TLR4 antagonists, as, for instance, trehalose derivatives [136].

Other negatively charged, monosaccharide-based TLR4 antagonists have been recently developed. Compound FP7 (Figure 6) inhibited the LPS-triggered, TLR4-mediated cytokine production in cells [137], and was found to be very active to contrast in vivo the TLR4-mediated lethality associated to influenza virus infection [52]. The mechanism of action of FP7, as in the case of IAXO compounds, is based on a combination of a direct competition with LPS for MD-2 binding and interaction with CD14. It was observed that, upon administration of FP7, CD14 endocytosis is stimulated so that after a certain time no CD14 is present on the plasma membrane [137]. The selective deprivation of CD14 from the cellular membrane is a peculiar mechanism adopted by this type of monosaccharide antagonists to inhibit TLR4 activation and signaling.

\subsection{Chalcone Derivatives and Curcumin Analogues}

A series of structurally related compounds (Figure 7) sharing the cynnamoyl fragment are known as MD-2 binders. Trimethoxychalcone L6H21 improved the survival of C57BL/6 mice after LPS administration as compared to untreated animals [138]. Binding to MD-2 was confirmed by surface plasmon resonance (SPR). Similar chalcones were effective in the LPS-induced acute lung injury model [139]. L48H37 was rationally designed as a curcumin analogue (Figure 7): it is stable under physiological conditions and binds to MD-2 [140], as confirmed by fluorescence spectroscopy and surface plasmon resonance (SPR) assays. Male C57BL/6 mice were injected with $200 \mu \mathrm{L}$ of LPS (at $20 \mathrm{mg} / \mathrm{kg}$ i.v.) 15 minutes before (for treatment) or after (for prevention) the administration of L48H37 (10 mg/kg i.v.). After seven days, both treatment and prevention groups have shown significantly better survival $(p<0.01)$ than LPS-injected animals. Curcumin itself has proven effective on TLR4-signaling [141-143]. The recent meta-analysis of randomized controlled trials (609 subjects overall) has shown that curcumin consumption significantly decreases IL-6 plasma levels, especially by system inflammation [144].<smiles>COc1ccc(C(=O)/C=C/c2cccc(OC)c2OC)cc1</smiles>

L6H21<smiles>O=C(/C=C/c1ccc(O)c(O)c1)N1CCCCC1</smiles>

Caffeic acid cyclohexylamide<smiles>COc1ccc(/C=C2\CN([13CH3])C/C(=C\c3ccc(OC)c(OC)c3OC)C2=O)c(OC)c1OC</smiles>

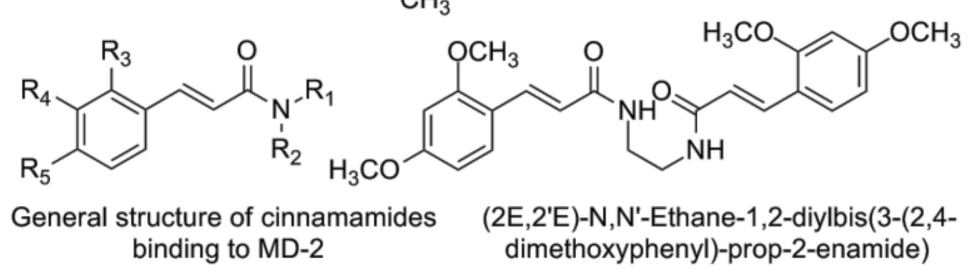

Figure 7. Chalcone L6H21, curcumin analogue L48H37 (upper row, from left to right), caffeic acid cyclohexylamide, general structure of synthesized cinnamamides, and the most active compound (from left to right, lower row).

Chen et al. [145] have prepared the series of various cinnamamides (Figure 7). Just as previously mentioned L48H37, they also have cinnamoyl fragment and bind to MD-2 as well. More than 30 compounds have been synthesized and tested in vitro on their ability to supress TNF- $\alpha$ production by mouse peritoneal macrophages after LPS stimulation. (2E,2'E)-N,N'-Ethane-1,2-diylbis(3-(2,4dimethoxyphenyl)-prop-2-enamide) had been chosen among the four most promising structures 
and investigated in more detail. In C57 mice, the protection against LPS-injection induced sepsis (intraperitoneally) was observed and the survival rate was significantly increased. Caffeic acid cyclohexylamide (Figure 7, lower row, left) also belongs to the cynnamamides but in contrary to aforementioned compounds do not bind to MD-2. It was shown to inhibit IKK $\beta$-kinase activity [146] and consequently the transcriptional activity of NF- $\mathrm{B}$. This caffeic acid derivative also rescued C57BL/6J mice after LPS-injection or CLP-induced sepsis, the group treated with $100 \mathrm{mg} / \mathrm{kg}$ dose showed $80 \%$ survival rate.

\subsection{Other Compounds}

In a double-blind, placebo-controlled study performed on male subjects (humans), simvastatin (Figure 8) caused statistically significant attenuation of LPS-induced TLR4 up-regulation in monocytes [147]. The substance was administered orally $80 \mathrm{mg}$ a day. Also a decrease of TNF- $\alpha$ and MCP-1 plasma levels after LPS administration was noted.<smiles>CCC(C)(C)C(=O)O[C@H]1C[C@H](C)C=C2C=C[C@H](C)[C@H](CC[C@@H]3C[C@H](O)CC(=O)O3)[C@H]2[C@H]1C</smiles>

Simvastatin<smiles>Cc1ccc(NCc2ccc(F)cc2)c(N)c1</smiles><smiles>COc1ccc(CNc2ccc(C)cc2N)cc1</smiles>

Figure 8. Simvastatin, FC-98 and FC-99 (from left to right).

In addition to the natural IRAK4 inhibitors mentioned above, the synthetic benzenediamine FC-99 (Figure 8) was proven to bind to IRAK4 both in silico and in vitro (SPR assay) [148]. FC-99 protected mice in the CLP-induced polymicrobial sepsis model and significantly decreased the serum levels of TNF- $\alpha$ and IL-6. A quite similar benzenediamine FC-98 also improved survival before as well as after LPS challenge [149]. In vitro blocking of both TLR4/NF- KB and TLR4/IRF3 pathways was observed. This finding is consistent with the existence of TRAF3-meditates bypass from IRAK1 to IRF3 [150].

Other important classes of natural and synthetic TLR4 antagonists have been reviewed recently by us and others (ref [115]). New TLR4 antagonists have been discovered in last two years, including synthetic compounds, such as fatty acid esters of monogalactosyl-diacylglycerol, trimannoside glycolipid conjugates (MGC), lipid A mimetic with Vizantin-like branched chains, morphine derivatives, and natural compounds as platycodin $\mathrm{D}$, ferulic acid, chalcones, etc. and will be reviewed by us elsewhere (manuscript in preparation).

\subsection{In Silico Studies}

Compounds with TLR4-antagonstic activity were identified in silico among 100 structures sharing similarity greater than 70\% to Eritoran, a known TLR4 antagonist, in the library consisting of 124413264 compounds. Testing on tissue obtained from Swiss Webster (CFW) mice has demonstrated that these substances inhibited LPS-induced NF-kB activation [151]. Pre-treatment with any of aforementioned compounds prior to LPS administration led to less severe symptoms of septic shock. Treatment with isopropyl 3,4,6-tri-O-acetyl-2-(acetylamino)-2-deoxyhexopyranoside, $\mathrm{C}=10 \mu \mathrm{M}$, reduced TNF $\alpha$ mRNA levels in human necrotizing enterocolitis tissue. IL-6 levels were also attenuated after LPS-stimulation as determined by ELISA method (C3H/WT cells) [151]. In silico approaches to design and discovery of new TLR4 modulators are discussed in a recent review [152]. Several other reviews are also devoted to the computational approaches to the discovery of the new TLR4-modulators [153-155]. 


\section{Peptide TLR4 Modulators}

We focus now on antagonists of TLR-4 signaling which have a peptide structure. As we discussed above, for the TLR4-mediated signal transduction multiple protein-protein interactions are necessary. A valuable strategy for TLR4 antagonism would therefore be the use of short peptides that mimic protein epitopes and disrupt interactions of TLR4 with MD-2 or other adaptor proteins containing TIR domains.

\subsection{Peptides that Disrupt the TLR4/MD-2 Interaction}

A 17-residue peptide was projected in silico as a mimic of TLR4-binding region of human MD-2 (hMD-2) and synthesized [156]. This peptide (sequence: CRGSDDDYSFCRALKGE) bound to TLR4 with higher affinity than $\mathrm{hMD} 2(\Delta \mathrm{G}=-7.8 \mathrm{kcal} / \mathrm{mol} \mathrm{vs}-5.5 \mathrm{kcal} / \mathrm{mol})$.

Han et al. [157] have constructed decoy protein, which comprised the structure motifs necessary for interaction with MD2 and thus a competitive inhibitor was obtained. The mutation experiments led to the decoy receptor variants possessing higher affinity to MD-2.

\subsection{Peptides that Disrupt TIR/TIR Interactions}

TIRAP decoy peptides were designed and synthesized to disrupt the interaction of the TLR4-TIR domain with adapter proteins necessary for the downstream signaling [158]. It has been known that both TLRs and their adapter proteins have TIR domain that mediates the interactions necessary for the signal transduction [159-161]. TIRAP peptides blocked both MyD88-dependent and MyD88-independent cytokine genes induced by LPS, and consisted of 10-14 amino acid residues. Among them, five peptides were found to inhibit cytokine gene expression as well as MAPK after LPS stimulation [158]. In vivo, IL- 6 and TNF- $\alpha$ concentrations were also attenuated in murine blood by the two most active peptides after administration of a sublethal LPS dose.

The same research group has designed and prepared TRAM adapter TIR domain derived decoy proteins applying the same approach [162]. Two of eleven peptides, IVFAEMPCGRLHLQ and ENFLRDTWCNFQFY, were the most potent to inhibit expression and secretion of all cytokines considered (TNF- $\alpha$, IL-1 $\beta$, IL-6, RANTES, IFN- $\beta$ ) in vitro. The activation of MAPKs was also inhibited. Co-immunoprecipitation assays have shown that these peptides block adapter recruitment to TLR4. Six truncated variants of IVFAEMPCGRLHLQ were also synthesized. The pentapeptide IVFAE was the most active among them and more potent than precursor with longer sequence. When administrated to the C57BL/6J mice, IVFAEMPCGRLHLQ, ENFLRDTWCNFQFY, and IVFAEMPCG effectively suppressed LPS-induced cytokine induction and protected animals from lethal endotoxemia after sublethal LPS dose. Treatment of mice with $10 \mathrm{nmol} / \mathrm{g}$ of peptide before the injection of LPS on the LD100 level either rescued all the animals (IVFAEMPCGRLHLQ and IVFAEMPCG) or at least part of them (77\%, ENFLRDTWCNFQFY). Reversing the order of administration of peptides and LPS similar results were obtained.

Another way to block TLR4 signaling is to inhibit the dimerization of TLR4 TIR domains, which occurs by the stimulation of agonist and is necessary for downstream signal transduction. 12 peptides (each was 9-14 amino acids long) reproducing different parts of TIR-domain were synthesized and tested in vitro on murine macrophages stimulated by LPS. Five of them were the most active ones to reduce cytokines expression (IL-1 $\beta$, TNF- $\alpha$, IFN- $\beta$, and RANTES mRNA). Among these five, three (LHYRDFIPGVAIAA, AGCKKYSRGESIYD, and HIFWRRLKNALLD) demonstrated the best affinity to TLR4-TIR as have been shown by time-resolved fluorescence spectroscopy [163]. The same group also has designed and synthesized TRIF TIR domain-derived decoy peptides [164]. They also were effective in vivo, decreasing LPS-induced cytokine response and improving survival of mice after LPS challenge.

Decoy peptides designed to reproduce the binding part of TIR-domain of TcpB/Btp1 protein from Brucella spp. were also tested as blockers of protein-protein interactions necessary for TLR4 signal 
transduction [165]. The assumption was that TcpB/Btp1 can interact with adaptors downstream of TLRs, prevent NF- $\mathrm{kB}$ activation, and consequently diminish cytokine production, which is important for innate antibacterial immune response [166]. In vitro, two of the twelve synthesized peptides significantly inhibited mRNA expression of both MyD88-dependent (TNF- $\alpha$ and IL-1 $\beta$ ) or TRIF-dependent (IFN- $\beta$ ) cytokines as well as their secretion. In Balb/c mice, pre-treatment with peptides significantly decreased cytokine levels after LPS administration.

It is worth to note that TIR homologue proteins occur in other bacterial species, including Salmonella enterica [167], Staphylococcus aureus [168]. Such proteins can modulate the host immune response [169]. Bacterial proteins containing TIR-domains are discussed in review by Rana et al. [170].

One more TRAM-derived peptide inhibits the inflammatory response in mouse mammary epithelial cells and a mastitis model in mice [171]. Hines et al. [172] have prepared blood-brain barrier (BBB)-permeating peptides, 18 amino acids long, to inhibit TLR4-MyD88 interaction. At concentration $3 \mu \mathrm{M}, \mathrm{TNF}-\alpha$ production in the murine brain tissue after LPS stimulation was significantly decreased (ex vivo). Prior to peptide injection, the mice were treated with LPS. After that, these peptides were tested in vivo using intraperitoneal administration. Then, TNF- $\alpha$ level in whole brain lysate were measured by ELISA method. In the brain tissue, ex vivo TNF- $\alpha$ level were also decreased after LPS stimulation as compared with LPS control $(p=0.030$ and $p<0.001)$. A short peptide (11 amino acid residues) VIPER of vaccinia virus A46 protein on both murine (iBMDM) and human cells (THP-1 and PBMC) in vitro at concentrations significantly decreased TNF- $\alpha$ production after LPS-stimulation (E. coli). Inhibiting resulted from the blocking interaction of TLR4 with Mal (TIRAP) and TRAM adaptor proteins [173]. Epta-peptides derived from BB-loop region of Toll/IL-1 receptor (TIR) domain also inhibited homodimerization of MyD88 TIR domains in vitro [174]. TIR-signaling modulation has been described in a review [175]. Therapeutic targets belonging to the TLR4 signaling pathway are discussed by Roy et al. [176]. It was concluded that disrupting the TLR4/ NF- $\mathrm{kB}$ pathway is a promising strategy to treat inflammatory disorders but it should not be blocked for long time because of its huge role in the host immune response.

\section{Discussion and Conclusions}

The TLR4 antagonists described in this review are synthetic or natural molecules belonging to different classes of compounds, from glycolipids to chalcone derivatives, to terpenoids, to peptides.

These molecules have diverse modes of action, blocking the TLR4 signal at various stages and binding to their targets non-covalently as well as covalently. The exact targets of some TLR signaling pathway blockers are not clear yet and the hypotheses generated by docking studies need experimental validation. Many compounds that decreased pro-inflammatory cytokines (TNF- $\alpha$, IL-6, IL-1 $\beta$, IFN- $\gamma$ ) concentration after LPS stimulation in cell-based assays were also active in vivo on murine model, improving survival and decreasing the cytokine levels.

Among all TLR4 antagonists so far developed, only TAK-242 and Eritoran reached clinical trials, but unfortunately failed to pass them and were not active in improving patients survival [124,129-132]. At phase 3 of clinical trials, Eritoran was not active in improving survival also for sepsis patients infected by Gram-negative flora ( 21.9 vs $22.3 \%, p=0.89$ ), although for this subgroup a positive effect was expected. The negative results in clinic were in contrast with successful applications of TLR4 antagonists in sepsis therapy in animal models. This "translational gap" is well known in a series of other drugs, in the case of sepsis it could derive from the difference in TLR4 signaling and in the expression of inflammatory pathway genes in humans and in mice.

In a comparative review written by Vaure and Liu [177], the expression patterns of TLR4 in different tissues and mammal species were analyzed, and the relative sensibility of various animal species to LPS also considered. When compared to humans, mice are less susceptible to LPS, with the threshold dose required for minimal physiological changes is $0.5 \mathrm{mg} / \mathrm{kg}$ intraperitoneally for mice [178] (BALB/c strain) vs $1-5 \mathrm{ng} / \mathrm{kg}$ intravenously for humans [179]. This is a substantial difference even 
considering the diverse susceptibility across the mouse strains. One of the possible reasons for that is the difference in cytokine production patterns [177].

It is also known that after LPS stimulation in mouse neutrophils and peritoneal macrophages, a decrease in TLR4 expression occurs [180], in contrast, TLR4 expression in human monocytes is unaltered at least after low doses of lipopolysaccharide [181]. Cytokine production and NF-kB DNA-binding activity are also suppressed in mice [182]. Moreover, several mRNA isoforms of TLR4 in mice are known [183]. A notable one is smTLR4 (soluble mouse TLR4). This splicing variant consists of 122 amino acid residues, is not membrane-bound, and contains a part of the TLR4 extracellular domain responsible for the interaction with LPS. One possible reason can be the inhibition of TLR4/MD-2 interaction since MD-2 is known to be essential in mediating the LPS response. smTLR4 can therefore be an endogenous TLR4-antagonist acting on the early stages of TLR4 signaling. There is not an equivalent of such TLR4 isoform in humans.

It is also important to consider the similarity between animal sepsis models and human sepsis. As stated before, the CLP model mimics human sepsis the most but rarely was used in the studies reported in this review. The LPS injection model was often employed, which reproduces septic shock rather than sepsis. So for further development of TLR4-signaling modulators, their testing on CLP sepsis model is also recommended.

Taken together, these factors underline the great differences between murine and human innate immune response to LPS and explain, at least in part, the clinical gap in the case of sepsis.

Because of the complexity of innate immunity regulation, and also because of the redundancy of pathways involved in TLR-triggered cytokine production, in the future combined therapies could be investigated and tested in clinic.

One possibility could be to combine TLR4 antagonists with specific antibacterial agents.

Wang et al. [111] have studied the effect of the TLR4 antagonist artemisinin alone and in combination with antibiotics on the mice survival after administration of live E. coli bacteria as a source of LPS. When ampicillin sodium or a 2:1 mixture of ampicillin sodium/sulbactam sodium were co-administrated to the bacterium, the survival increased to $33 \%$ and $67 \%$, respectively. When administering antibiotics alone, a $0 \%$ and 33\% survival increase was obtained. Conversely, when administrating Artemisin alone, no protection was obtained after the injection of live E. coli bacteria.

Another case when TLR4 antagonist was given together with antimicrobial substance was described by Shirey and co-workers [51], albeit the disease was influenza and not sepsis. Applied together with Tamiflu ${ }^{\mathrm{TM}}$ (oseltamivir), Eritoran significantly improved the survival of C57BL/6J mice as compared with the group given oseltamivir alone, and protected them from lethal re-infection.

A second possibility is the combination of blockers of different TLRs. In a recent successful example, anti-TLR2 and anti-TLR4 monoclonal antibodies were combined [184]. When metronidazole and ceftriaxone have been co-administrated with TLR4-targeting immunoglobulins, the survival increased more than twice when comparing with anti-TLR4 antibodies alone.

Concerning pathologies related to PAMP/TLR4 activation, in particular in the case of acute sepsis and septic shock, one can therefore conclude that, despite promising results on animal models, the clinical trials based on a single TLR4 antagonist has not led so far to a significant improvement in survival. We propose here combination therapies as a new strategy to overcome the limitations discussed above.

The use of TLR4 modulators in pathologies caused by TLR4 activation by endogenous DAMPs, however, is still at a very early stage and promising results have been obtained at a preclinical stage. Some small-molecular TLR4 blockers displayed a lack of toxicity and were efficient in blocking DAMP/TLR4 signaling and cytokine production in an array of inflammatory and autoimmune diseases [185-187]. These comprise of neuropathic pain, ALS, rheumatoid arthritis, vascular inflammation, atherosclerosis, and other pathologies reviewed here. 
We are therefore convinced that some modern day chronic inflammations and autoimmune diseases that still lack specific pharmacological treatment could be efficiently targeted by new drugs interfering with TLR(4) activation and signaling.

Acknowledgments: Nikolay N. Kuzmich acknowledges Olga Petina (KRKA) and Roman Shutov (Vertex) for valuable critical remarks regarding the manuscript. FP acknowledges the H2020-MSC-ETN-642157 project TOLLerant and the Italian Ministry for Foreign Affairs and International Cooperation (MAECI).

Author Contributions: Nikolay N. Kuzmich wrote the paper; Konstantin V. Sivak participated in writing of the introduction section and performed the literature search together with Vladimir N. Chubarev, Yury B. Porozov and Tatiana N. Savateeva-Lyubimova; Francesco Peri reorganized and updated the manuscript with new data.

Conflicts of Interest: The authors declare no conflict of interest.

\section{References}

1. Kawai, T.; Akira, S. The role of pattern-recognition receptors in innate immunity: Update on toll-like receptors. Nat. Immunol. 2010, 11, 373-384. [CrossRef] [PubMed]

2. O'Neill, L.A.; Golenbock, D.; Bowie, A.G. The history of toll-like receptors-Redefining innate immunity. Nat. Rev. Immunol. 2013, 13, 453-460. [CrossRef] [PubMed]

3. Poltorak, A.; He, X.; Smirnova, I.; Liu, M.; Van Huffel, C.; Du, X.; Birdwell, D.; Alejos, E.; Silva, M.; Galanos, C.; et al. Defective LPS signaling in C3H/HEJ and C57BL/10SCCR mice: Mutations in TLR4 gene. Science 1998, 282, 2085-2088. [CrossRef] [PubMed]

4. Beutler, B. TLR4 as the mammalian endotoxin sensor. Curr. Top Microbiol. Immunol. 2002, 270, 109-120. [PubMed]

5. Beutler, B.; Du, X.; Poltorak, A. Identification of toll-like receptor 4 (TLR4) as the sole conduit for LPS signal transduction: Genetic and evolutionary studies. J. Endotoxin Res. 2001, 7, 277-280. [CrossRef] [PubMed]

6. Kobe, B.; Deisenhofer, J. The leucine-rich repeat: A versatile binding motif. Trends Biochem. Sci. 1994, 19, 415-421. [CrossRef]

7. Shimazu, R.; Akashi, S.; Ogata, H.; Nagai, Y.; Fukudome, K.; Miyake, K.; Kimoto, M. Md-2, a molecule that confers lipopolysaccharide responsiveness on toll-like receptor 4. J. Exp. Med. 1999, 189, 1777-1782. [CrossRef] [PubMed]

8. Gioannini, T.; Teghanemt, A.; Zhang, D.; Levis, E.; Weiss, J. Monomeric endotoxin: Protein complexes are essential for TLR4-dependent cell activation. J. Endotoxin Res. 2005, 11, 117-123. [CrossRef] [PubMed]

9. Gioannini, T.; Teghanemt, A.; Zhang, D.; Coussens, N.; Dockstader, W.; Ramaswamy, S.; Weiss, J. Isolation of an endotoxin-MD-2 complex that produces toll-like receptor 4-dependent cell activation at picomolar concentrations. Proc. Natl. Acad. Sci. USA 2004, 101, 4186-4191. [CrossRef] [PubMed]

10. Park, B.; Song, D.; Kim, H.; Choi, B.; Lee, H.; Lee, J. The structural basis of lipopolysaccharide recognition by the TLR4-MD-2 complex. Nature 2009, 458, 1191-1195. [CrossRef] [PubMed]

11. Kim, S.J.; Kim, H.M. Dynamic lipopolysaccharide transfer cascade to TLR4/MD2 complex via LBP and CD14. BMB Rep. 2017, 50, 55-57. [CrossRef] [PubMed]

12. Ryu, J.K.; Kim, S.J.; Rah, S.H.; Kang, J.I.; Jung, H.E.; Lee, D.; Lee, H.K.; Lee, J.O.; Park, B.S.; Yoon, T.Y.; et al. Reconstruction of LPS transfer cascade reveals structural determinants within LBP, CD14, and TLR4-MD2 for efficient LPS recognition and transfer. Immunity 2017, 46, 38-50. [CrossRef] [PubMed]

13. Kitchens, R. Role of CD14 in cellular recognition of bacterial lipopolysaccharides. Chem. Immunol. 2000, 74, 61-82. [PubMed]

14. O'Neill, L.A.; Bowie, A.G. The family of five: TIR-domain-containing adaptors in toll-like receptor signalling. Nat. Rev. Immunol. 2007, 7, 353-364. [CrossRef] [PubMed]

15. Guven-Maiorov, E.; Keskin, O.; Gursoy, A.; VanWaes, C.; Chen, Z.; Tsai, C.J.; Nussinov, R. The architecture of the TIR domain signalosome in the toll-like receptor-4 signaling pathway. Sci. Rep. 2015, 5, 13128. [CrossRef] [PubMed]

16. Shim, D.W.; Heo, K.H.; Kim, Y.K.; Sim, E.J.; Kang, T.B.; Choi, J.W.; Sim, D.W.; Cheong, S.H.; Lee, S.H.; Bang, J.K.; et al. Anti-inflammatory action of an antimicrobial model peptide that suppresses the TRIF-dependent signalling pathway via inhibition of toll-like receptor 4 endocytosis in lipopolysaccharide-stimulated macrophages. PLoS ONE 2015, 10, e0126871. [CrossRef] [PubMed] 
17. Zanoni, I.; Ostuni, R.; Marek, L.R.; Barresi, S.; Barbalat, R.; Barton, G.M.; Granucci, F.; Kagan, J.C. CD14 controls the LPS-induced endocytosis of toll-like receptor 4. Cell 2011, 147, 868-880. [CrossRef] [PubMed]

18. Valkov, E.; Stamp, A.; Dimaio, F.; Baker, D.; Verstak, B.; Roversi, P.; Kellie, S.; Sweet, M.J.; Mansell, A.; Gay, N.J.; et al. Crystal structure of toll-like receptor adaptor mal/tirap reveals the molecular basis for signal transduction and disease protection. Proc. Natl. Acad. Sci. USA 2011, 108, 14879-14884. [CrossRef] [PubMed]

19. Lin, Z.; Lu, J.; Zhou, W.; Shen, Y. Structural insights into TIR domain specificity of the bridging adaptor mal in TLR4 signaling. PLoS ONE 2012, 7, e34202. [CrossRef] [PubMed]

20. Lin, S.C.; Lo, Y.C.; Wu, H. Helical assembly in the MyD88-IRAK4-IRAK2 complex in TLR/IL-1r signalling. Nature 2010, 465, 885-890. [CrossRef] [PubMed]

21. Ferrao, R.; Zhou, H.; Shan, Y.; Liu, Q.; Li, Q.; Shaw, D.E.; Li, X.; Wu, H. Irak4 dimerization and trans-autophosphorylation are induced by myddosome assembly. Mol. Cell 2014, 55, 891-903. [CrossRef] [PubMed]

22. Wang, C.; Deng, L.; Hong, M.; Akkaraju, G.R.; Inoue, J.; Chen, Z.J. TAK1 is a ubiquitin-dependent kinase of MKK and IKK. Nature 2001, 412, 346-351. [CrossRef] [PubMed]

23. Landstrom, M. The TAK1-TRAF6 signalling pathway. Int. J. Biochem. Cell Biol. 2010, 42, 585-589. [CrossRef] [PubMed]

24. Akira, S.; Takeda, K. Toll-like receptor signalling. Nat. Rev. Immunol. 2004, 4, 499-511. [CrossRef] [PubMed]

25. Enokizono, Y.; Kumeta, H.; Funami, K.; Horiuchi, M.; Sarmiento, J.; Yamashita, K.; Standley, D.M.; Matsumoto, M.; Seya, T.; Inagaki, F. Structures and interface mapping of the tir domain-containing adaptor molecules involved in interferon signaling. Proc. Natl. Acad. Sci. USA 2013, 110, 19908-19913. [CrossRef] [PubMed]

26. Gay, N.J.; Symmons, M.F.; Gangloff, M.; Bryant, C.E. Assembly and localization of toll-like receptor signalling complexes. Nat. Rev. Immunol. 2014, 14, 546-558. [CrossRef] [PubMed]

27. Funami, K.; Sasai, M.; Oshiumi, H.; Seya, T.; Matsumoto, M. Homo-oligomerization is essential for toll/interleukin-1 receptor domain-containing adaptor molecule-1-mediated NF-kappaB and interferon regulatory factor-3 activation. J. Biol. Chem. 2008, 283, 18283-18291. [CrossRef] [PubMed]

28. Heipertz, E.L.; Harper, J.; Walker, W.E. Sting and trif contribute to mouse sepsis, depending on severity of the disease model. Shock 2017, 47, 621-631. [CrossRef] [PubMed]

29. Liu, S.; Cai, X.; Wu, J.; Cong, Q.; Chen, X.; Li, T.; Du, F.; Ren, J.; Wu, Y.T.; Grishin, N.V.; et al. Phosphorylation of innate immune adaptor proteins mavs, sting, and trif induces IRF3 activation. Science 2015, 347, aaa2630. [CrossRef] [PubMed]

30. Honda, K.; Takaoka, A.; Taniguchi, T. Type I interferon [corrected] gene induction by the interferon regulatory factor family of transcription factors. Immunity 2006, 25, 349-360. [CrossRef] [PubMed]

31. Lee, K.M.; Seong, S.Y. Partial role of TLR4 as a receptor responding to damage-associated molecular pattern. Immunol. Lett. 2009, 125, 31-39. [CrossRef] [PubMed]

32. Tsung, A.; Sahai, R.; Tanaka, H.; Nakao, A.; Fink, M.; Lotze, M.; Yang, H.; Li, J.; Tracey, K.; Geller, D.; et al. The nuclear factor HMGB1 mediates hepatic injury after murine liver ischemia-reperfusion. J. Exp. Med. 2005, 201, 1135-1143. [CrossRef] [PubMed]

33. Goligorsky, M.S. TLR4 and HMGB1: Partners in crime? Kidney Int. 2011, 80, 450-452. [CrossRef] [PubMed]

34. Erridge, C. The roles of toll-like receptors in atherosclerosis. J. Innate Immun. 2009, 1, 340-349. [CrossRef] [PubMed]

35. Abdollahi-Roodsaz, S.; Joosten, L.A.; Roelofs, M.F.; Radstake, T.R.; Matera, G.; Popa, C.; van der Meer, J.W.; Netea, M.G.; van den Berg, W.B. Inhibition of toll-like receptor 4 breaks the inflammatory loop in autoimmune destructive arthritis. Arthritis Rheum. 2007, 56, 2957-2967. [CrossRef] [PubMed]

36. Cao, L.; Tanga, F.; Deleo, J. The contributing role of cd14 in toll-like receptor 4 dependent neuropathic pain. Neuroscience 2009, 158, 896-903. [CrossRef] [PubMed]

37. Fan, J.; Li, Y.; Levy, R.M.; Fan, J.J.; Hackam, D.J.; Vodovotz, Y.; Yang, H.; Tracey, K.J.; Billiar, T.R.; Wilson, M.A. Hemorrhagic shock induces NAD $(\mathrm{P}) \mathrm{H}$ oxidase activation in neutrophils: Role of HMGB1-TLR4 signaling. J. Immunol. 2007, 178, 6573-6580. [CrossRef] [PubMed]

38. Bachtell, R.; Hutchinson, M.R.; Wang, X.; Rice, K.C.; Maier, S.F.; Watkins, L.R. Targeting the toll of drug abuse: The translational potential of Toll-like receptor 4. CNS Neurol. Disord. Drug Targets 2015, 14, 692-699. [CrossRef] [PubMed] 
39. Liu, J.; Buisman-Pijlman, F.; Hutchinson, M.R. Toll-like receptor 4: Innate immune regulator of neuroimmune and neuroendocrine interactions in stress and major depressive disorder. Front. Neurosci. 2014, 8, 309. [CrossRef] [PubMed]

40. Wu, M.K.; Huang, T.L.; Huang, K.W.; Huang, Y.L.; Hung, Y.Y. Association between toll-like receptor 4 expression and symptoms of major depressive disorder. Neuropsychiatr. Dis. Treat. 2015, 11, 1853-1857. [PubMed]

41. De Paola, M.; Sestito, S.E.; Mariani, A.; Memo, C.; Fanelli, R.; Freschi, M.; Bendotti, C.; Calabrese, V.; Peri, F. Synthetic and natural small molecule TLR4 antagonists inhibit motoneuron death in cultures from ALS mouse model. Pharmacol. Res. 2016, 103, 180-187. [CrossRef] [PubMed]

42. Thakur, K.K.; Saini, J.; Mahajan, K.; Singh, D.; Jayswal, D.P.; Mishra, S.; Bishayee, A.; Sethi, G.; Kunnumakkara, A.B. Therapeutic implications of toll-like receptors in peripheral neuropathic pain. Pharmacol. Res. 2017, 115, 224-232. [CrossRef] [PubMed]

43. Bettoni, I.; Comelli, F.; Rossini, C.; Granucci, F.; Giagnoni, G.; Peri, F.; Costa, B. Glial TLR4 receptor as new target to treat neuropathic pain: Efficacy of a new receptor antagonist in a model of peripheral nerve injury in mice. Glia 2008, 56, 1312-1319. [CrossRef] [PubMed]

44. Levy, M.M.; Fink, M.P.; Marshall, J.C.; Abraham, E.; Angus, D.; Cook, D.; Cohen, J.; Opal, S.M.; Vincent, J.L.; Ramsay, G.; et al. 2001 SCCM/ESICM/ACCP/ATS/SIS international sepsis definitions conference. Intensive Care Med. 2003, 29, 530-538. [CrossRef] [PubMed]

45. Singer, M.; Deutschman, C.S.; Seymour, C.W.; Shankar-Hari, M.; Annane, D.; Bauer, M.; Bellomo, R.; Bernard, G.R.; Chiche, J.D.; Coopersmith, C.M.; et al. The third international consensus definitions for sepsis and septic shock (sepsis-3). JAMA 2016, 315, 801-810. [CrossRef] [PubMed]

46. Fleischmann, C.; Scherag, A.; Adhikari, N.K.; Hartog, C.S.; Tsaganos, T.; Schlattmann, P.; Angus, D.C.; Reinhart, K. International Forum of Acute Care Trialists. Assessment of global incidence and mortality of hospital-treated sepsis. Current estimates and limitations. Am. J. Respir. Crit. Care Med. 2016, 193, $259-272$. [CrossRef] [PubMed]

47. Suarez De La Rica, A.; Gilsanz, F.; Maseda, E. Epidemiologic trends of sepsis in western countries. Ann. Transl. Med. 2016, 4, 325. [CrossRef] [PubMed]

48. Keynan, Y.; Fowke, K.R.; Ball, T.B.; Meyers, A.F.A. Toll-like receptors dysregulation after influenza virus infection: Insights into pathogenesis of subsequent bacterial pneumonia. ISRN Pulmonol. 2011, 2011. [CrossRef]

49. Shah, N.S.; Greenberg, J.A.; McNulty, M.C.; Gregg, K.S.; Riddell, J.T.; Mangino, J.E.; Weber, D.M.; Hebert, C.L.; Marzec, N.S.; Barron, M.A.; et al. Bacterial and viral co-infections complicating severe influenza: Incidence and impact among 507 U.S. Patients, 2013-14. J. Clin. Virol. Off. Publ. Pan Am. Soc. Clin. Virol. 2016, 80, 12-19. [CrossRef] [PubMed]

50. Crum-Cianflone, N.F. Invasive aspergillosis associated with severe influenza infections. Open Forum Infect. Dis. 2016, 3, ofw171. [CrossRef] [PubMed]

51. Shirey, K.A.; Lai, W.; Scott, A.J.; Lipsky, M.; Mistry, P.; Pletneva, L.M.; Karp, C.L.; McAlees, J.; Gioannini, T.L.; Weiss, J.; et al. The TLR4 antagonist eritoran protects mice from lethal influenza infection. Nature 2013, 497, 498-502. [CrossRef] [PubMed]

52. Perrin-Cocon, L.; Aublin-Gex, A.; Sestito, S.E.; Shirey, K.A.; Patel, M.C.; André, P.; Blanco, J.C.; Vogel, S.N.; Peri, F.; Lotteau, V. TLR4 antagonist FP7 inhibits LPS-induced cytokine production and glycolytic reprogramming in dendritic cells, and protects mice from lethal influenza infection. Sci. Rep. 2017, 7, 40791. [CrossRef] [PubMed]

53. Decker, T. Sepsis: Avoiding its deadly toll. J. Clin. Investig. 2004, 113, 1387-1389. [CrossRef] [PubMed]

54. Lakshmikanth, C.L.; Jacob, S.P.; Chaithra, V.H.; de Castro-Faria-Neto, H.C.; Marathe, G.K. Sepsis: In search of cure. Inflamm. Res. Off. J. Eur. Histamine Res. Soc. 2016, 65, 587-602. [CrossRef] [PubMed]

55. Philp, A.M.; Davis, E.T.; Jones, S.W. Developing anti-inflammatory therapeutics for patients with osteoarthritis. Rheumatology 2017, 56, 869-881. [CrossRef] [PubMed]

56. Neuman, M.G.; Maor, Y.; Nanau, R.M.; Melzer, E.; Mell, H.; Opris, M.; Cohen, L.; Malnick, S. Alcoholic liver disease: Role of cytokines. Biomolecules 2015, 5, 2023-2034. [CrossRef] [PubMed]

57. Wittebole, X.; Castanares-Zapatero, D.; Laterre, P.F. Toll-like receptor 4 modulation as a strategy to treat sepsis. Mediat. Inflamm. 2010, 2010, 568396. [CrossRef] [PubMed] 
58. Savva, A.; Roger, T. Targeting toll-like receptors: Promising therapeutic strategies for the management of sepsis-associated pathology and infectious diseases. Front. Immunol. 2013, 4, 387. [CrossRef] [PubMed]

59. Stortz, J.A.; Raymond, S.L.; Mira, J.C.; Moldawer, L.L.; Mohr, A.M.; Efron, P.A. Murine models of sepsis and trauma: Can we bridge the gap? ILAR J. 2017, 58, 90-105. [CrossRef] [PubMed]

60. Deitch, E.A. Animal models of sepsis and shock: A review and lessons learned. Shock 1998, 9, 1-11. [CrossRef] [PubMed]

61. Buras, J.A.; Holzmann, B.; Sitkovsky, M. Animal models of sepsis: Setting the stage. Nat. Rev. Drug Dis. 2005, 4, 854-865. [CrossRef] [PubMed]

62. Seemann, S.; Zohles, F.; Lupp, A. Comprehensive comparison of three different animal models for systemic inflammation. J. Biomed. Sci. 2017, 24, 60. [CrossRef] [PubMed]

63. Fink, M.P.; Heard, S.O. Laboratory models of sepsis and septic shock. J. Surg. Res. 1990, 49, $186-196$. [CrossRef]

64. Dejager, L.; Pinheiro, I.; Dejonckheere, E.; Libert, C. Cecal ligation and puncture: The gold standard model for polymicrobial sepsis? Trends Microbiol. 2011, 19, 198-208. [CrossRef] [PubMed]

65. Hubbard, W.J.; Choudhry, M.; Schwacha, M.G.; Kerby, J.D.; Rue, L.W., III; Bland, K.I.; Chaudry, I.H. Cecal ligation and puncture. Shock 2005, 24, S52-S57. [CrossRef]

66. Pinsky, M.R.; Vincent, J.L.; Deviere, J.; Alegre, M.; Kahn, R.J.; Dupont, E. Serum cytokine levels in human septic shock. Relation to multiple-system organ failure and mortality. Chest 1993, 103, 565-575. [CrossRef] [PubMed]

67. Wichterman, K.A.; Baue, A.E.; Chaudry, I.H. Sepsis and septic shock-A review of laboratory models and a proposal. J. Surg. Res. 1980, 29, 189-201. [CrossRef]

68. Chu, M.; Ding, R.; Chu, Z.Y.; Zhang, M.B.; Liu, X.Y.; Xie, S.H.; Zhai, Y.J.; Wang, Y.D. Role of berberine in anti-bacterial as a high-affinity lps antagonist binding to TLR4/MD-2 receptor. BMC Complement. Altern. Med. 2014, 14, 89. [CrossRef] [PubMed]

69. Morris, G.M.; Goodsell, D.S.; Halliday, R.S.; Huey, R.; Hart, W.E.; Belew, R.K.; Olson, A.J. Automated docking using a lamarckian genetic algorithm and an empirical binding free energy function. J. Comput. Chem. 1998, 19, 1639-1662. [CrossRef]

70. Huey, R.; Morris, G.M.; Olson, A.J.; Goodsell, D.S. A semiempirical free energy force field with charge-based desolvation. J. Comput. Chem. 2007, 28, 1145-1152. [CrossRef] [PubMed]

71. Pandey, M.K.; Sung, B.; Kunnumakkara, A.B.; Sethi, G.; Chaturvedi, M.M.; Aggarwal, B.B. Berberine modifies cysteine 179 of Ikappabalpha kinase, suppresses nuclear factor-kappab-regulated antiapoptotic gene products, and potentiates apoptosis. Cancer Res. 2008, 68, 5370-5379. [CrossRef] [PubMed]

72. Li, S.; Gao, X.; Wu, X.; Wu, Z.; Cheng, L.; Zhu, L.; Shen, D.; Tong, X. Parthenolide inhibits LPS-induced inflammatory cytokines through the toll-like receptor 4 signal pathway in THP-1 cells. Acta Biochim. Biophys. Sin. 2015, 47, 368-375. [CrossRef] [PubMed]

73. Nam, Y.J.; Lee, D.H.; Lee, M.S.; Lee, C.S. Sesquiterpene lactone parthenolide attenuates production of inflammatory mediators by suppressing the toll-like receptor-4-mediated activation of the AKT, mTOR, and NF-kappaB pathways. Naunyn-Schmiedeberg Arch. Pharmacol. 2015, 388, 921-930. [CrossRef] [PubMed]

74. Saadane, A.; Masters, S.; DiDonato, J.; Li, J.; Berger, M. Parthenolide inhibits IkappaB kinase, NF-kappaB activation, and inflammatory response in cystic fibrosis cells and mice. Am. J. Respir. Cell Mol. Biol. 2007, 36, 728-736. [CrossRef] [PubMed]

75. Park, S.J.; Shin, H.J.; Youn, H.S. Parthenolide inhibits TRIF-dependent signaling pathway of toll-like receptors in raw264.7 macrophages. Mol. Cells 2011, 31, 261-265. [CrossRef] [PubMed]

76. Sheehan, M.; Wong, H.R.; Hake, P.W.; Malhotra, V.; O'Connor, M.; Zingarelli, B. Parthenolide, an inhibitor of the nuclear factor-kappab pathway, ameliorates cardiovascular derangement and outcome in endotoxic shock in rodents. Mol. Pharmacol. 2002, 61, 953-963. [CrossRef] [PubMed]

77. Li, X.; Cui, X.; Li, Y.; Fitz, Y.; Hsu, L.; Eichacker, P.Q. Parthenolide has limited effects on nuclear factor-kappa beta increases and worsens survival in lipopolysaccharide-challenged C57BL/6J mice. Cytokine 2006, 33, 299-308. [CrossRef] [PubMed]

78. Kong, F.C.; Zhang, J.Q.; Zeng, C.; Chen, W.L.; Ren, W.X.; Yan, G.X.; Wang, H.X.; Li, Q.B.; Chen, Z.C. Inhibitory effects of parthenolide on the activity of NF-kappaB in multiple myeloma via targeting TRAF6. J. Huazhong Univ. Sci. Technol. Med. Sci. 2015, 35, 343-349. [CrossRef] [PubMed] 
79. Liang, Q.; Wu, Q.; Jiang, J.; Duan, J.; Wang, C.; Smith, M.D.; Lu, H.; Wang, Q.; Nagarkatti, P.; Fan, D. Characterization of sparstolonin $b$, a Chinese herb-derived compound, as a selective toll-like receptor antagonist with potent anti-inflammatory properties. J. Biol. Chem. 2011, 286, 26470-26479. [CrossRef] [PubMed]

80. Liang, Q.; Dong, S.; Lei, L.; Liu, J.; Zhang, J.; Li, J.; Duan, J.; Fan, D. Protective effects of sparstolonin b, a selective TLR2 and TLR4 antagonist, on mouse endotoxin shock. Cytokine 2015, 75, 302-309. [CrossRef] [PubMed]

81. Wang, M.; Xiu, L.; Diao, J.; Wei, L.; Sun, J. Sparstolonin b inhibits lipopolysaccharide-induced inflammation in 3T3-L1 adipocytes. Eur. J. Pharmacol. 2015, 769, 79-85. [CrossRef] [PubMed]

82. Liang, Q.; Yu, F.; Cui, X.; Duan, J.; Wu, Q.; Nagarkatti, P.; Fan, D. Sparstolonin b suppresses lipopolysaccharide-induced inflammation in human umbilical vein endothelial cells. Arch. Pharmacal Res. 2013, 36, 890-896. [CrossRef] [PubMed]

83. Ji, G.; Chen, R.; Zheng, J. Atractylenolide i inhibits lipopolysaccharide-induced inflammatory responses via mitogen-activated protein kinase pathways in raw264.7 cells. Immunopharmacol. Immunotoxicol. 2014, 36, 420-425. [CrossRef] [PubMed]

84. Zhang, J.L.; Huang, W.M.; Zeng, Q.Y. Atractylenolide I protects mice from lipopolysaccharide-induced acute lung injury. Eur. J. Pharmacol. 2015, 765, 94-99. [CrossRef] [PubMed]

85. Wang, A.; Xiao, Z.; Zhou, L.; Zhang, J.; Li, X.; He, Q. The protective effect of atractylenolide I on systemic inflammation in the mouse model of sepsis created by cecal ligation and puncture. Pharm. Biol. 2016, 54, 146-150. [CrossRef] [PubMed]

86. Li, C.Q.; He, L.C.; Jin, J.Q. Atractylenolide I and atractylenolide III inhibit lipopolysaccharide-induced TNF-alpha and no production in macrophages. Phytother. Res. PTR 2007, 21, 347-353. [CrossRef] [PubMed]

87. Chen, Y.F.; Shiau, A.L.; Wang, S.H.; Yang, J.S.; Chang, S.J.; Wu, C.L.; Wu, T.S. Zhankuic acid a isolated from taiwanofungus camphoratus is a novel selective TLR4/MD-2 antagonist with anti-inflammatory properties. J. Immunol. 2014, 192, 2778-2786. [CrossRef] [PubMed]

88. Moustakas, D.T.; Lang, P.T.; Pegg, S.; Pettersen, E.; Kuntz, I.D.; Brooijmans, N.; Rizzo, R.C. Development and validation of a modular, extensible docking program: Dock 5. J. Comput.-Aided Mol. Des. 2006, 20, 601-619. [CrossRef] [PubMed]

89. Wang, R.; Lai, L.; Wang, S. Further development and validation of empirical scoring functions for structure-based binding affinity prediction. J. Comput.-Aided Mol. Des. 2002, 16, 11-26. [CrossRef] [PubMed]

90. Lee, J.Y.; Lee, B.H.; Kim, N.D.; Lee, J.Y. Celastrol blocks binding of lipopolysaccharides to a toll-like receptor4/myeloid differentiation factor 2 complex in a thiol-dependent manner. J. Ethnopharmacol. 2015, 172, 254-260. [CrossRef] [PubMed]

91. Veerappan, K.; Natarajan, S.; Ethiraj, P.; Vetrivel, U.; Samuel, S. Inhibition of Ikkbeta by celastrol and its analogues-An in silico and in vitro approach. Pharm. Biol. 2017, 55, 368-373. [CrossRef] [PubMed]

92. Li, Z.; Xiao, X.; Yang, M. Asiatic acid inhibits lipopolysaccharide-induced acute lung injury in mice. Inflammation 2016, 39, 1642-1648. [CrossRef] [PubMed]

93. Patil, K.R.; Mohapatra, P.; Patel, H.M.; Goyal, S.N.; Ojha, S.; Kundu, C.N.; Patil, C.R. Pentacyclic triterpenoids inhibit Ikkbeta mediated activation of NF-kappab pathway: In silico and in vitro evidences. PLoS ONE 2015, 10, e0125709. [CrossRef] [PubMed]

94. Kim, T.H.; Yoon, S.J.; Lee, S.M. Genipin attenuates sepsis by inhibiting toll-like receptor signaling. Mol. Med. 2012, 18, 455-465. [CrossRef] [PubMed]

95. Song, Y.; Dou, H.; Gong, W.; Liu, X.; Yu, Z.; Li, E.; Tan, R.; Hou, Y. Bis-n-norgliovictin, a small-molecule compound from marine fungus, inhibits LPS-induced inflammation in macrophages and improves survival in sepsis. Eur. J. Pharmacol. 2013, 705, 49-60. [CrossRef] [PubMed]

96. Kim, J.S.; Kim, S.J.; Lee, S.M. Genipin attenuates sepsis-induced immunosuppression through inhibition of T lymphocyte apoptosis. Int. Immunopharmacol. 2015, 27, 15-23. [CrossRef] [PubMed]

97. Park, S.H.; Baek, S.I.; Yun, J.; Lee, S.; Yoon, D.Y.; Jung, J.K.; Jung, S.H.; Hwang, B.Y.; Hong, J.T.; Han, S.B.; et al. IRAK4 as a molecular target in the amelioration of innate immunity-related endotoxic shock and acute liver injury by chlorogenic acid. J. Immunol. 2015, 194, 1122-1130. [CrossRef] [PubMed]

98. Park, S.H.; Roh, E.; Kim, H.S.; Baek, S.I.; Choi, N.S.; Kim, N.; Hwang, B.Y.; Han, S.B.; Kim, Y. Inhibition of IRAK-4 activity for rescuing endotoxin LPS-induced septic mortality in mice by lonicerae flos extract. Biochem. Biophys. Res. Commun. 2013, 442, 183-188. [CrossRef] [PubMed] 
99. Kim, M.J.; Bae, G.S.; Jo, I.J.; Choi, S.B.; Kim, D.G.; Shin, J.Y.; Lee, S.K.; Kim, M.J.; Shin, S.; Song, H.J.; et al. Loganin protects against pancreatitis by inhibiting NF-kappaB activation. Eur. J. Pharmacol. 2015, 765, 541-550. [CrossRef] [PubMed]

100. Hossen, M.J.; Yang, W.S.; Kim, D.; Aravinthan, A.; Kim, J.H.; Cho, J.Y. Thymoquinone: An IRAK1 inhibitor with in vivo and in vitro anti-inflammatory activities. Sci. Rep. 2017, 7, 42995. [CrossRef] [PubMed]

101. Alkharfy, K.M.; Ahmad, A.; Raish, M.; Vanhoutte, P.M. Thymoquinone modulates nitric oxide production and improves organ dysfunction of sepsis. Life Sci. 2015, 143, 131-138. [CrossRef] [PubMed]

102. Alkharfy, K.M.; Al-Daghri, N.M.; Al-Attas, O.S.; Alokail, M.S. The protective effect of thymoquinone against sepsis syndrome morbidity and mortality in mice. Int. Immunopharmacol. 2011, 11, 250-254. [CrossRef] [PubMed]

103. Li, X. IRAK4 in TLR/IL-1r signaling: Possible clinical applications. Eur. J. Immunol. 2008, 38, 614-618. [CrossRef] [PubMed]

104. Seganish, W.M. Inhibitors of interleukin-1 receptor-associated kinase 4 (IRAK4): A patent review (2012-2015). Expert Opin. Ther. Pat. 2016, 26, 917-932. [CrossRef] [PubMed]

105. Tumey, L.N.; Boschelli, D.H.; Bhagirath, N.; Shim, J.; Murphy, E.A.; Goodwin, D.; Bennett, E.M.; Wang, M.; Lin, L.L.; Press, B.; et al. Identification and optimization of indolo[2,3-c]quinoline inhibitors of IRAK4. Bioorg. Med. Chem. Lett. 2014, 24, 2066-2072. [CrossRef] [PubMed]

106. Patra, M.C.; Choi, S. Recent progress in the molecular recognition and therapeutic importance of interleukin-1 receptor-associated kinase 4. Molecules 2016, 21. [CrossRef] [PubMed]

107. Chaudhary, D.; Robinson, S.; Romero, D.L. Recent advances in the discovery of small molecule inhibitors of interleukin-1 receptor-associated kinase 4 (IRAK4) as a therapeutic target for inflammation and oncology disorders. J. Med. Chem. 2015, 58, 96-110. [CrossRef] [PubMed]

108. Kelly, P.N.; Romero, D.L.; Yang, Y.; Shaffer, A.L., III; Chaudhary, D.; Robinson, S.; Miao, W.; Rui, L.; Westlin, W.F.; Kapeller, R.; et al. Selective interleukin-1 receptor-associated kinase 4 inhibitors for the treatment of autoimmune disorders and lymphoid malignancy. J. Exp. Med. 2015, 212, 2189-2201. [CrossRef] [PubMed]

109. Li, B.; Zhang, R.; Li, J.; Zhang, L.; Ding, G.; Luo, P.; He, S.; Dong, Y.; Jiang, W.; Lu, Y.; et al. Antimalarial artesunate protects sepsis model mice against heat-killed escherichia coli challenge by decreasing TLR4, TLR9 mRNA expressions and transcription factor NF-kappa B activation. Int. Immunopharmacol. 2008, 8, 379-389. [CrossRef] [PubMed]

110. Wang, D.; Shi, J.; Lv, S.; Xu, W.; Li, J.; Ge, W.; Xiao, C.; Geng, D.; Liu, Y. Artesunate attenuates lipopolysaccharide-stimulated proinflammatory responses by suppressing TLR4, MyD88 expression, and NF-kappaB activation in microglial cells. Inflammation 2015, 38, 1925-1932. [CrossRef] [PubMed]

111. Wang, J.; Zhou, H.; Zheng, J.; Cheng, J.; Liu, W.; Ding, G.; Wang, L.; Luo, P.; Lu, Y.; Cao, H.; et al. The antimalarial artemisinin synergizes with antibiotics to protect against lethal live escherichia coli challenge by decreasing proinflammatory cytokine release. Antimicrob. Agents Chemother. 2006, 50, 2420-2427. [CrossRef] [PubMed]

112. Li, H.R.; Liu, J.; Zhang, S.L.; Luo, T.; Wu, F.; Dong, J.H.; Guo, Y.J.; Zhao, L. Corilagin ameliorates the extreme inflammatory status in sepsis through TLR4 signaling pathways. BMC Complement. Altern. Med. 2017, $17,18$. [CrossRef] [PubMed]

113. Singh, A.K.; Umar, S.; Riegsecker, S.; Chourasia, M.; Ahmed, S. Regulation of transforming growth factor beta-activated kinase activation by epigallocatechin-3-gallate in rheumatoid arthritis synovial fibroblasts: Suppression of k(63) -linked autoubiquitination of tumor necrosis factor receptor-associated factor 6. Arthritis Rheumatol. 2016, 68, 347-358. [CrossRef] [PubMed]

114. Wheeler, D.S.; Lahni, P.M.; Hake, P.W.; Denenberg, A.G.; Wong, H.R.; Snead, C.; Catravas, J.D.; Zingarelli, B. The green tea polyphenol epigallocatechin-3-gallate improves systemic hemodynamics and survival in rodent models of polymicrobial sepsis. Shock 2007, 28, 353-359. [CrossRef] [PubMed]

115. Peri, F; Calabrese, V. Toll-like receptor 4 (TLR4) modulation by synthetic and natural compounds: An update. J. Med. Chem. 2014, 57, 3612-3622. [CrossRef] [PubMed]

116. Takashima, K.; Matsunaga, N.; Yoshimatsu, M.; Hazeki, K.; Kaisho, T.; Uekata, M.; Hazeki, O.; Akira, S.; Iizawa, Y.; Ii, M. Analysis of binding site for the novel small-molecule TLR4 signal transduction inhibitor TAK-242 and its therapeutic effect on mouse sepsis model. Br. J. Pharmacol. 2009, 157, 1250-1262. [CrossRef] [PubMed] 
117. Matsunaga, N.; Tsuchimori, N.; Matsumoto, T.; Ii, M. TAK-242 (resatorvid), a small-molecule inhibitor of toll-like receptor (TLR) 4 signaling, binds selectively to TLR4 and interferes with interactions between TLR4 and its adaptor molecules. Mol. Pharmacol. 2011, 79, 34-41. [CrossRef] [PubMed]

118. Sha, T.; Sunamoto, M.; Kitazaki, T.; Sato, J.; Ii, M.; Iizawa, Y. Therapeutic effects of TAK-242, a novel selective toll-like receptor 4 signal transduction inhibitor, in mouse endotoxin shock model. Eur. J. Pharmacol. 2007, 571, 231-239. [CrossRef] [PubMed]

119. Sha, T.; Iizawa, Y.; Ii, M. Combination of imipenem and TAK-242, a toll-like receptor 4 signal transduction inhibitor, improves survival in a murine model of polymicrobial sepsis. Shock 2011, 35, 205-209. [CrossRef] [PubMed]

120. Hua, F.; Tang, H.; Wang, J.; Prunty, M.C.; Hua, X.; Sayeed, I.; Stein, D.G. TAK-242, an antagonist for toll-like receptor 4, protects against acute cerebral ischemia/reperfusion injury in mice. J. Cereb. Blood Flow Metab. Off. J. Int. Soc. Cereb. Blood Flow Metab. 2015, 35, 536-542. [CrossRef] [PubMed]

121. Fenhammar, J.; Rundgren, M.; Hultenby, K.; Forestier, J.; Taavo, M.; Kenne, E.; Weitzberg, E.; Eriksson, S.; Ozenci, V.; Wernerson, A.; et al. Renal effects of treatment with a TLR4 inhibitor in conscious septic sheep. Crit. Care 2014, 18, 488. [CrossRef] [PubMed]

122. Kuno, M.; Nemoto, K.; Ninomiya, N.; Inagaki, E.; Kubota, M.; Matsumoto, T.; Yokota, H. The novel selective toll-like receptor 4 signal transduction inhibitor TAK-242 prevents endotoxaemia in conscious guinea-pigs. Clin. Exp. Pharmacol. Physiol. 2009, 36, 589-593. [CrossRef] [PubMed]

123. Garate, I.; Garcia-Bueno, B.; Madrigal, J.L.; Caso, J.R.; Alou, L.; Gomez-Lus, M.L.; Leza, J.C. Toll-like 4 receptor inhibitor TAK-242 decreases neuroinflammation in rat brain frontal cortex after stress. J. Neuroinflamm. 2014, 11, 8. [CrossRef] [PubMed]

124. Rice, T.W.; Wheeler, A.P.; Bernard, G.R.; Vincent, J.L.; Angus, D.C.; Aikawa, N.; Demeyer, I.; Sainati, S.; Amlot, N.; Cao, C.; et al. A randomized, double-blind, placebo-controlled trial of TAK-242 for the treatment of severe sepsis. Crit. Care Med. 2010, 38, 1685-1694. [CrossRef] [PubMed]

125. Thomas, G.G.S.S.C.Z. Preparation of Deuterated Cyclohexenes as Modulators of TLR4 Signaling for Disease Treatment. U.S. Patent No. US 20090022706 A1, 2009.

126. Kim, H.; Park, B.; Kim, J.; Kim, S.; Lee, J.; Oh, S.; Enkhbayar, P.; Matsushima, N.; Lee, H.; Yoo, O.; et al. Crystal structure of the TLR4-MD-2 complex with bound endotoxin antagonist eritoran. Cell 2007, 130, 906-917. [CrossRef] [PubMed]

127. Bennett-Guerrero, E.; Grocott, H.P.; Levy, J.H.; Stierer, K.A.; Hogue, C.W.; Cheung, A.T.; Newman, M.F.; Carter, A.A.; Rossignol, D.P.; Collard, C.D. A phase II, double-blind, placebo-controlled, ascending-dose study of eritoran (e5564), a lipid a antagonist, in patients undergoing cardiac surgery with cardiopulmonary bypass. Anesth. Analg. 2007, 104, 378-383. [CrossRef] [PubMed]

128. Barochia, A.; Solomon, S.; Cui, X.; Natanson, C.; Eichacker, P.Q. Eritoran tetrasodium (e5564) treatment for sepsis: Review of preclinical and clinical studies. Expert Opin. Drug Metab. Toxicol. 2011, 7, 479-494. [CrossRef] [PubMed]

129. Tidswell, M.; LaRosa, S.P. Toll-like receptor-4 antagonist eritoran tetrasodium for severe sepsis. Expert Rev. Anti-Infect. Ther. 2011, 9, 507-520. [CrossRef] [PubMed]

130. Rossignol, D.P.; Wong, N.; Noveck, R.; Lynn, M. Continuous pharmacodynamic activity of eritoran tetrasodium, a TLR4 antagonist, during intermittent intravenous infusion into normal volunteers. Innate Immun. 2008, 14, 383-394. [CrossRef] [PubMed]

131. Opal, S.M.; Laterre, P.F.; Francois, B.; LaRosa, S.P.; Angus, D.C.; Mira, J.P.; Wittebole, X.; Dugernier, T.; Perrotin, D.; Tidswell, M.; et al. Effect of eritoran, an antagonist of MD2-TLR4, on mortality in patients with severe sepsis: The access randomized trial. JAMA 2013, 309, 1154-1162. [CrossRef] [PubMed]

132. Tidswell, M.; Tillis, W.; Larosa, S.P.; Lynn, M.; Wittek, A.E.; Kao, R.; Wheeler, J.; Gogate, J.; Opal, S.M.; Eritoran Sepsis Study, G. Phase 2 trial of eritoran tetrasodium (e5564), a toll-like receptor 4 antagonist, in patients with severe sepsis. Crit. Care Med. 2010, 38, 72-83. [CrossRef] [PubMed]

133. Lee, C.; An, H.J.; Kim, J.L.; Lee, H.; Paik, S.G. Inhibitory effect of a phosphatidyl ethanolamine derivative on LPS-induced sepsis. Mol. Cells 2009, 27, 251-255. [CrossRef] [PubMed]

134. Piazza, M.; Rossini, C.; Della Fiorentina, S.; Pozzi, C.; Comelli, F.; Bettoni, I.; Fusi, P.; Costa, B.; Peri, F. Glycolipids and benzylammonium lipids as novel antisepsis agents: Synthesis and biological characterization. J. Med. Chem. 2009, 52, 1209-1213. [CrossRef] [PubMed] 
135. Piazza, M.; Yu, L.; Teghanemt, A.; Gioannini, T.; Weiss, J.; Peri, F. Evidence of a specific interaction between new synthetic antisepsis agents and CD14. Biochemistry 2009, 48, 12337-12344. [CrossRef] [PubMed]

136. Rodriguez Lavado, J.; Sestito, S.E.; Cighetti, R.; Aguilar Moncayo, E.M.; Oblak, A.; Lainšček, D.; Jiménez Blanco, J.L.; García Fernández, J.M.; Ortiz Mellet, C.; Jerala, R.; et al. Trehalose- and glucose-derived glycoamphiphiles: Small-molecule and nanoparticle toll-like receptor 4 (TLR4) modulators. J. Med. Chem. 2014, 57, 9105-9123. [CrossRef] [PubMed]

137. Cighetti, R.; Ciaramelli, C.; Sestito, S.E.; Zanoni, I.; Kubik, Ł.; Ardá-Freire, A.; Calabrese, V.; Granucci, F.; Jerala, R.; Martín-Santamaría, S.; et al. Modulation of cd14 and TLR4·MD-2 activities by a synthetic lipid a mimetic. Chembiochem 2014, 15, 250-258. [CrossRef] [PubMed]

138. Wang, Y.; Shan, X.; Chen, G.; Jiang, L.; Wang, Z.; Fang, Q.; Liu, X.; Wang, J.; Zhang, Y.; Wu, W.; et al. MD-2 as the target of a novel small molecule, 16h21, in the attenuation of LPS-induced inflammatory response and sepsis. Br. J. Pharmacol. 2015, 172, 4391-4405. [CrossRef] [PubMed]

139. Zhang, Y.; Wu, J.; Ying, S.; Chen, G.; Wu, B.; Xu, T.; Liu, Z.; Liu, X.; Huang, L.; Shan, X.; et al. Discovery of new MD2 inhibitor from chalcone derivatives with anti-inflammatory effects in LPS-induced acute lung injury. Sci. Rep. 2016, 6, 25130. [CrossRef] [PubMed]

140. Wang, Y.; Shan, X.; Dai, Y.; Jiang, L.; Chen, G.; Zhang, Y.; Wang, Z.; Dong, L.; Wu, J.; Guo, G.; et al. Curcumin analog $148 \mathrm{~h} 37$ prevents lipopolysaccharide-induced TLR4 signaling pathway activation and sepsis via targeting MD2. J. Pharmacol. Exp. Ther. 2015, 353, 539-550. [CrossRef] [PubMed]

141. Wang, J.; Wang, H.; Zhu, R.; Liu, Q.; Fei, J.; Wang, S. Anti-inflammatory activity of curcumin-loaded solid lipid nanoparticles in IL-1beta transgenic mice subjected to the lipopolysaccharide-induced sepsis. Biomaterials 2015, 53, 475-483. [CrossRef] [PubMed]

142. Youn, H.S.; Saitoh, S.I.; Miyake, K.; Hwang, D.H. Inhibition of homodimerization of toll-like receptor 4 by curcumin. Biochem. Pharmacol. 2006, 72, 62-69. [CrossRef] [PubMed]

143. Gradisar, H.; Keber, M.M.; Pristovsek, P.; Jerala, R. MD-2 as the target of curcumin in the inhibition of response to LPS. J. Leukoc. Biol. 2007, 82, 968-974. [CrossRef] [PubMed]

144. Derosa, G.; Maffioli, P.; Simental-Mendia, L.E.; Bo, S.; Sahebkar, A. Effect of curcumin on circulating interleukin-6 concentrations: A systematic review and meta-analysis of randomized controlled trials. Pharmacol. Res. 2016, 111, 394-404. [CrossRef] [PubMed]

145. Chen, G.; Zhang, Y.; Liu, X.; Fang, Q.; Wang, Z.; Fu, L.; Liu, Z.; Wang, Y.; Zhao, Y.; Li, X.; et al. Discovery of a new inhibitor of myeloid differentiation 2 from cinnamamide derivatives with anti-inflammatory activity in sepsis and acute lung injury. J. Med. Chem. 2016, 59, 2436-2451. [CrossRef] [PubMed]

146. Choi, J.H.; Park, S.H.; Jung, J.K.; Cho, W.J.; Ahn, B.; Yun, C.Y.; Choi, Y.P.; Yeo, J.H.; Lee, H.; Hong, J.T.; et al. Caffeic acid cyclohexylamide rescues lethal inflammation in septic mice through inhibition of Ikappab kinase in innate immune process. Sci. Rep. 2017, 7, 41180. [CrossRef] [PubMed]

147. Niessner, A.; Steiner, S.; Speidl, W.S.; Pleiner, J.; Seidinger, D.; Maurer, G.; Goronzy, J.J.; Weyand, C.M.; Kopp, C.W.; Huber, K.; et al. Simvastatin suppresses endotoxin-induced upregulation of toll-like receptors 4 and 2 in vivo. Atherosclerosis 2006, 189, 408-413. [CrossRef] [PubMed]

148. Dou, H.; Song, Y.; Liu, X.; Yang, L.; Jiang, N.; Chen, D.; Li, E.; Tan, R.; Hou, Y. A novel benzenediamine derivate rescued mice from experimental sepsis by attenuating proinflammatory mediators via IRAK4. Am. J. Respir. Cell Mol. Biol. 2014, 51, 191-200. [PubMed]

149. Song, Y.; Liu, X.; Yue, H.; Ji, J.; Dou, H.; Hou, Y. Anti-inflammatory effects of benzenediamine derivate FC-98 on sepsis injury in mice via suppression of JNK, NF-kappaB and IRF3 signaling pathways. Mol. Immunol. 2015, 67, 183-192. [CrossRef] [PubMed]

150. Oganesyan, G.; Saha, S.K.; Guo, B.; He, J.Q.; Shahangian, A.; Zarnegar, B.; Perry, A.; Cheng, G. Critical role of TRAF3 in the toll-like receptor-dependent and -independent antiviral response. Nature 2006, 439, $208-211$. [CrossRef] [PubMed]

151. Wipf, P.N.; Sodhi, C.P.; Hackam, D.J. Novel TLR4 inhibitors for the treatment of human infectious and inflammatory disorders. PCT International Application No. PCT/ US2011/053293 Publication No. WO 2012040719 A2, 29 May 2015.

152. Billod, J.M.; Lacetera, A.; Guzman-Caldentey, J.; Martin-Santamaria, S. Computational approaches to toll-like receptor 4 modulation. Molecules 2016, 21. [CrossRef] [PubMed] 
153. Klett, J.; Reeves, J.; Oberhauser, N.; Perez-Regidor, L.; Martin-Santamaria, S. Modulation of toll-like receptor 4. Insights from X-ray crystallography and molecular modeling. Curr. Top. Med. Chem. 2014, 14, 2672-2683. [CrossRef] [PubMed]

154. Perez-Regidor, L.; Zarioh, M.; Ortega, L.; Martin-Santamaria, S. Virtual screening approaches towards the discovery of toll-like receptor modulators. Int. J. Mol. Sci. 2016, 17. [CrossRef] [PubMed]

155. Murgueitio, M.S.; Rakers, C.; Frank, A.; Wolber, G. Balancing inflammation: Computational design of small-molecule toll-like receptor modulators. Trends Pharmacol. Sci. 2017, 38, 155-168. [CrossRef] [PubMed]

156. Slivka, P.; Shridhar, M.; Lee, G.; Sammond, D.; Hutchinson, M.; Martinko, A.; Buchanan, M.; Sholar, P.; Kearney, J.; Harrison, J.; et al. A peptide antagonist of the TLR4-MD2 interaction. Chembiochem 2009, 10, 645-649. [CrossRef] [PubMed]

157. Han, J.; Kim, H.J.; Lee, S.C.; Hong, S.; Park, K.; Jeon, Y.H.; Kim, D.; Cheong, H.K.; Kim, H.S. Structure-based rational design of a toll-like receptor 4 (TLR4) decoy receptor with high binding affinity for a target protein. PLOS ONE 2012, 7, e30929. [CrossRef] [PubMed]

158. Couture, L.A.; Piao, W.; Ru, L.W.; Vogel, S.N.; Toshchakov, V.Y. Targeting toll-like receptor (TLR) signaling by toll/interleukin-1 receptor (TIR) domain-containing adapter protein/myd88 adapter-like (TIRAP/MAL)-derived decoy peptides. J. Biol. Chem. 2012, 287, 24641-24648. [CrossRef] [PubMed]

159. Xu, Y.; Tao, X.; Shen, B.; Horng, T.; Medzhitov, R.; Manley, J.L.; Tong, L. Structural basis for signal transduction by the toll/interleukin-1 receptor domains. Nature 2000, 408, 111-115. [CrossRef] [PubMed]

160. Dunne, A.; Ejdeback, M.; Ludidi, P.L.; O’Neill, L.A.; Gay, N.J. Structural complementarity of toll/interleukin-1 receptor domains in toll-like receptors and the adaptors mal and myd88. J. Biol. Chem. 2003, 278, 41443-41451. [CrossRef] [PubMed]

161. Nunez Miguel, R.; Wong, J.; Westoll, J.F.; Brooks, H.J.; O’Neill, L.A.; Gay, N.J.; Bryant, C.E.; Monie, T.P. A dimer of the toll-like receptor 4 cytoplasmic domain provides a specific scaffold for the recruitment of signalling adaptor proteins. PLoS ONE 2007, 2, e788. [CrossRef] [PubMed]

162. Piao, W.; Vogel, S.N.; Toshchakov, V.Y. Inhibition of TLR4 signaling by tram-derived decoy peptides in vitro and in vivo. J. Immunol. 2013, 190, 2263-2272. [CrossRef] [PubMed]

163. Toshchakov, V.Y.; Szmacinski, H.; Couture, L.A.; Lakowicz, J.R.; Vogel, S.N. Targeting TLR4 signaling by TLR4 Toll/IL-1 receptor domain-derived decoy peptides: Identification of the TLR4 Toll/IL-1 receptor domain dimerization interface. J. Immunol. 2011, 186, 4819-4827. [CrossRef] [PubMed]

164. Piao, W.; Ru, L.W.; Piepenbrink, K.H.; Sundberg, E.J.; Vogel, S.N.; Toshchakov, V.Y. Recruitment of tlr adapter TRIF to TLR4 signaling complex is mediated by the second helical region of TRIF TIR domain. Proc. Natl. Acad. Sci. USA 2013, 110, 19036-19041. [CrossRef] [PubMed]

165. Ke, Y.; Li, W.; Wang, Y.; Yang, M.; Guo, J.; Zhan, S.; Du, X.; Wang, Z.; Yang, M.; Li, J.; et al. Inhibition of TLR4 signaling by brucella TIR-containing protein TCPB-derived decoy peptides. Int. J. Med. Microbiol. 2016, 306, 391-400. [CrossRef] [PubMed]

166. Arango Duque, G.; Descoteaux, A. Macrophage cytokines: Involvement in immunity and infectious diseases. Front. Immunol. 2014, 5, 491. [CrossRef] [PubMed]

167. Newman, R.M.; Salunkhe, P.; Godzik, A.; Reed, J.C. Identification and characterization of a novel bacterial virulence factor that shares homology with mammalian toll/interleukin-1 receptor family proteins. Infect. Immun. 2006, 74, 594-601. [CrossRef] [PubMed]

168. Patot, S.; Imbert, P.R.; Baude, J.; Martins Simoes, P.; Campergue, J.B.; Louche, A.; Nijland, R.; Bes, M.; Tristan, A.; Laurent, F.; et al. The tir homologue lies near resistance genes in staphylococcus aureus, coupling modulation of virulence and antimicrobial susceptibility. PLoS Pathog. 2017, 13, e1006092. [CrossRef]

169. Cirl, C.; Miethke, T. Microbial toll/interleukin 1 receptor proteins: A new class of virulence factors. Int. J. Med. Microbiol. 2010, 300, 396-401. [CrossRef] [PubMed]

170. Rana, R.R.; Zhang, M.; Spear, A.M.; Atkins, H.S.; Byrne, B. Bacterial TIR-containing proteins and host innate immune system evasion. Med. Microbiol. Immunol. 2013, 202, 1-10. [CrossRef] [PubMed]

171. Hu, X.; Tian, Y.; Wang, T.; Zhang, W.; Wang, W.; Gao, X.; Qu, S.; Cao, Y.; Zhang, N. Tram-derived decoy peptides inhibits the inflammatory response in mouse mammary epithelial cells and a mastitis model in mice. Eur. J. Pharmacol. 2015, 764, 607-612. [CrossRef] [PubMed]

172. Hines, D.J.; Choi, H.B.; Hines, R.M.; Phillips, A.G.; MacVicar, B.A. Prevention of LPS-induced microglia activation, cytokine production and sickness behavior with TLR4 receptor interfering peptides. PLoS ONE 2013, 8, e60388. [CrossRef] [PubMed] 
173. Lysakova-Devine, T.; Keogh, B.; Harrington, B.; Nagpal, K.; Halle, A.; Golenbock, D.T.; Monie, T.; Bowie, A.G. Viral inhibitory peptide of TLR4, a peptide derived from vaccinia protein a46, specifically inhibits TLR4 by directly targeting Myd88 adaptor-like and TRIF-related adaptor molecule. J. Immunol. 2010, 185, 4261-4271. [CrossRef] [PubMed]

174. Loiarro, M.; Sette, C.; Gallo, G.; Ciacci, A.; Fanto, N.; Mastroianni, D.; Carminati, P.; Ruggiero, V. Peptide-mediated interference of TIR domain dimerization in Myd88 inhibits interleukin-1-dependent activation of NF-\{kappa\}B. J. Biol. Chem. 2005, 280, 15809-15814. [CrossRef] [PubMed]

175. Li, X.; Qin, J. Modulation of toll-interleukin 1 receptor mediated signaling. J. Mol. Med. 2005, 83, $258-266$. [CrossRef] [PubMed]

176. Roy, A.; Srivastava, M.; Saqib, U.; Liu, D.; Faisal, S.M.; Sugathan, S.; Bishnoi, S.; Baig, M.S. Potential therapeutic targets for inflammation in toll-like receptor 4 (TLR4)-mediated signaling pathways. Int. Immunopharmacol. 2016, 40, 79-89. [CrossRef] [PubMed]

177. Vaure, C.; Liu, Y. A comparative review of toll-like receptor 4 expression and functionality in different animal species. Front. Immunol. 2014, 5, 316. [CrossRef] [PubMed]

178. Marcuzzi, A.; Secchiero, P.; Crovella, S.; Zauli, G. Trail administration down-modulated the acute systemic inflammatory response induced in a mouse model by muramyldipeptide or lipopolysaccharide. Cytokine 2012, 60, 43-46. [CrossRef] [PubMed]

179. Medicines and Healthcare products Regulatory Agency. Supplementary chapters sci basis of pharmacopeial requirements. In British Pharmacopeia; Medicines and Healthcare products Regulatory Agency: London, UK, 2012; Volume 5.

180. Muzio, M.; Bosisio, D.; Polentarutti, N.; D’Amico, G.; Stoppacciaro, A.; Mancinelli, R.; van't Veer, C.; Penton-Rol, G.; Ruco, L.P.; Allavena, P.; et al. Differential expression and regulation of toll-like receptors (tlr) in human leukocytes: Selective expression of TLR3 in dendritic cells. J. Immunol. 2000, 164, 5998-6004. [CrossRef] [PubMed]

181. Lichte, P.; Grigoleit, J.S.; Steiner, E.M.; Kullmann, J.S.; Schedlowski, M.; Oberbeck, R.; Kobbe, P. Low dose lps does not increase TLR4 expression on monocytes in a human in vivo model. Cytokine 2013, 63, 74-80. [CrossRef] [PubMed]

182. Iwami, K.I.; Matsuguchi, T.; Masuda, A.; Kikuchi, T.; Musikacharoen, T.; Yoshikai, Y. Cutting edge: Naturally occurring soluble form of mouse toll-like receptor 4 inhibits lipopolysaccharide signaling. J. Immunol. 2000, 165, 6682-6686. [CrossRef] [PubMed]

183. Akashi, S.; Shimazu, R.; Ogata, H.; Nagai, Y.; Takeda, K.; Kimoto, M.; Miyake, K. Cutting edge: Cell surface expression and lipopolysaccharide signaling via the toll-like receptor 4-MD-2 complex on mouse peritoneal macrophages. J. Immunol. 2000, 164, 3471-3475. [CrossRef] [PubMed]

184. Lima, C.X.; Souza, D.G.; Amaral, F.A.; Fagundes, C.T.; Rodrigues, I.P.; Alves-Filho, J.C.; Kosco-Vilbois, M.; Ferlin, W.; Shang, L.; Elson, G.; et al. Therapeutic effects of treatment with anti-TLR2 and anti-TLR4 monoclonal antibodies in polymicrobial sepsis. PLoS ONE 2015, 10, e0132336. [CrossRef] [PubMed]

185. Venkatesha, S.H.; Dudics, S.; Astry, B.; Moudgil, K.D. Control of autoimmune inflammation by celastrol, a natural triterpenoid. Pathog. Dis. 2016, 74. [CrossRef] [PubMed]

186. Li, G.; Liu, D.; Zhang, Y.; Qian, Y.; Zhang, H.; Guo, S.; Sunagawa, M.; Hisamitsu, T.; Liu, Y. Celastrol inhibits lipopolysaccharide-stimulated rheumatoid fibroblast-like synoviocyte invasion through suppression of tlr4/nf-kappab-mediated matrix metalloproteinase-9 expression. PLoS ONE 2013, 8, e68905. [CrossRef]

187. Wang, J.; Lu, J.; Lan, Y.; Zhou, H.; Li, W.; Xiang, M. Total coumarins from urtica dentata hand prevent murine autoimmune diabetes via suppression of the TLR4-signaling pathways. J. Ethnopharmacol. 2013, 146, 379-392. [CrossRef] [PubMed]

(C) 2017 by the authors. Licensee MDPI, Basel, Switzerland. This article is an open access article distributed under the terms and conditions of the Creative Commons Attribution (CC BY) license (http:/ / creativecommons.org/licenses/by/4.0/). 